\title{
GEOGRAPHICAL AND HUMAN IMPACT ELEMENTS INFLUENCE ON THE FISH FAUNA OF THE OLTEŢ RIVER (ROMANIA)
}

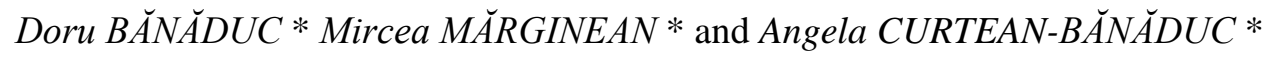 \\ * "Lucian Blaga" University of Sibiu, Faculty of Sciences, Dr. Ion Raţiu Street 5-7, Sibiu, Romania, \\ RO-550012,ad.banaduc@yahoo.com, mircea.marginean@yahoo.com, angela.banaduc@ulbsibiu.ro
}

DOI: 10.2478/trser-2013-0018

KEYWORDS: lotic biotopes, fish associations, Carpathian fish integrity index.

\section{ABSTRACT}

A white spot regarding the fish fauna of the upper and middle Oltet River was covered and the significant changes appeared in this respect and in the lower course were identified. In general the passing of the river from one type of geographical/relief type unit to another, induce the changing of the ichthyological zone and the increasing of the fish species number. There where this natural situation did not appear is because different human impact causes create unnatural variations in fish communities' compositions and individuals' number. The presence of a various human impact especially downstream the mountain area makes to exist here a relative unbalanced fish fauna structure, in comparison with the mountainous sector. Overall, the geographical and human impact elements, and a result of them, the self cleaning capacity of river, are main driving forces which induce the fish fauna composition variability.

ZUSAMMENFASSUNG: Der Einfluss geographischer Faktoren und menschlicher bedingter Faktoren auf die Fischfauna des Olteţ-Flusses (Rumänien).

Mit vorliegender Arbeit wurde ein weißer Fleck bezüglich der Fischfauna des oberen und mittleren Olteţ-Flusses ausgefüllt und dabei auch die dadurch aufgetretenen, signifikanten Veränderungen am Unterlauf identifiziert. Im allgemeinen führt der Übergang des Flusses von einer geographischen Einheit bzw. von einem Relieftyp zu einem anderen zu einem Wechsel der ichtyologischen Zone und einem Anwachsen der Anzahl von Fischarten. Warum diese natürliche Situation nicht auftritt, ergbit sich aus unterschiedlichen, menschlich bedingten Eingriffen, die unnatürliche Variationen in der Zusammensetzung der Fischgemeinschaften und Individuenzahl verursachen. Das Vorhandensein unterschiedlicher, menschlich bedingter Veränderungen, vor allem unterhalb des Gebirgsabschnittes führt dazu, dass hier im Vergleich zu den oberen Abschnitten des Flusses eine relativ unausgewogene Fischfaunastruktur vorzufinden ist. Überall sind die geographischen und menschlich bedingten Elemente und das Ergebnis ihrer Auswirkungen auf die Selbstreinigungskapazität des Flusses die Hauptkräfte, die Variabilität der Zusammensetzung der Fischfauna bestimmen.

REZUMAT: Influența elementelor geografice și antropice de impact asupra ihtiofaunei din râul Olteț (România).

A fost studiată ihtiofauna din cursul superior și mijlociu al râului Olteț, o zonă necercetată din acest punct de vedere până în prezent, de asemenea au fost evaluate schimbările în structura comunităților de pești față de situaţia de acum 50 de ani (Bănărescu, 1964) în cazul cursului inferior, evidențiindu-se modificări semnificative. În general, trecerea unui curs de apă de la un tip de unitate geografică sau de relief la alta face ca diversitatea ihtiocenozelor să crească spre aval. În zonele afectate de diverse tipuri de impact antropic, această tendinţă naturală nu se manifestă, iar structura comunităților de pești prezintă deviații majore de la starea naturală (în ceea ce privește compoziția specifică 
și numărul de indivizi). Prezența unei palete largi de tipuri de impact antropic, în special, în aval de zona montană duce la o structură a ihtiocenozelor relativ dezechilibrată prin comparație cu sectorul montan. Ca tendință generală, factorii de influență geografici și antropici și rezultanta lor, capacitatea de autoepurare a râului sunt principalele forțe care condiţionează variabilitatea structurii comunităților de pești.

\section{INTRODUCTION}

Grigore Antipa (1867-1944) the first great Romanian ichthyologist, realized the fact that Romania should have a nationwide territory approach in the fish fauna study. In order to help manage this very important natural resource, the first publication regarding the fish fauna of Romania was created (Antipa, 1909).

Petru Mihai Bănărescu (1921-2009), the greatest Romanian ichthyologist, deepened and extended this national approach, realizing the astonishingly publication regarding the fish fauna of Romania (Bănărescu, 1964), with an impressive quantity and quality of data, many of these data actual even today, after a half of a century.

Many researchers have worked, in this field of study, and have tried to complete this work, but the task is far from over due to relatively big Romanian national territory and mostly due to its high geographical variability. This variability induces a relatively high variability of the aquatic biotopes and of their ichthyocenosis, and due to the continuous and various human impacts on fish fauna habitats, the fish fauna variability also increases.

In this general context, it is easy to accept the need and the actuality of such inventory/assessment ichthyological studies, especially in rivers where: no data are available, rivers where long/significant sectors have no data available, or where the human impact and/or climate changes induced modifications in the fish habitats. Thus, new qualitative and quantitative fish fauna related aspects have appeared. Essentially, the fish communities' assessment, monitoring, management, protection, conservation, etc., cannot be done properly without such complete ichthyological surveys, as they are an initial data base for future comparisons. The numerous protected areas proposed and "managed" on fake data regarding their fish fauna is just an example of some of the unfortunate assessment, monitoring, management, protection and conservation of fish "on paper".

The Olteţ River fish fauna fits this type of situation, it was studied by Bănărescu (1964) in its very low sector; a sector which suffered intensive human impact, especially in the last half of the XXth century. Upstream, this relatively short studied lower sector (Bals ș locality - Olteț-Olt rivers confluence), a sector negatively affected by pollution, hidrotechnical works and habitats change. Until now, no ichthyologist has studied the river in the rest of its significant length. In spite of this situation, for example, and based on "theoretical” fish data, the "Cheile Olteţului"/“Olteţului Gorge” Protected Natural Area was proposed and designated to conserve fish species which never lived there.

This intensive (two years long sampling campaign) and extensive (the distance between the sampling stations are between one to three and a half $\mathrm{km}$ ) ichthyological study, serves as the first data base, for this important Carpathian river.

The Olteţ River is the main tributary of the $615 \mathrm{~km}$ long Olt River, one of the biggest affluent of the lower Danube River. The Olt Watershed $\left(24.439 \mathrm{~km}^{2} ; 10.1 \%\right.$ of the Romanian national territory) is situated in the central and southern part of Romania; springing in the Oriental Romanian Carpathians, passing to the west the Transylvanian Depression, south of the Meridional Romanian Carpathians, in the southern Romanian subcarpathians and the Romanian Plain until the convergence with the Danube (Diaconu and Stănculescu, 1971; Roşu, 1980; Posea, 1982; Badea, 1983; Sommerwerk et al., 2009). 
The upper and middle Olt Basin fish fauna was studied recently (Bănăduc, 1999, 2000, 2001; Bănăduc and Curtean-Bănăduc, 2002; Curtean-Bănăduc and Bănăduc 2004; CurteanBănăduc et al., 2014), the situation being significantly different in the lower part of the basin.

The Olteţ River springs in the Căpăţanii Mountains, which belong to the Parâng Massif and to the Romanian Meridional Carpathians; the mountainous area is limited at the east by the Olt River and in the west by the Jiu River (Velcea and Savu, 1982). It has a length of $615 \mathrm{~km}$ and a basin surface of 24,000 $\mathrm{km}^{2}$ (Posea et al., 1982).

The Olteţ River basin is situated in the south-southwest part of Romania (Fig. 1), flowing from north to south in its upper sector and from north-west to south-east in its middle and especially in its lower part, passing the administrative units Gorj, Vâlcea and Olt.

The Olteţ Valley geology is a varied one (different crystalline rocks, old and new eruptive rocks, sedimentary rocks, etc.) (Velcea and Savu, 1982), and is reason for which this river has a relatively high natural relief units variability (Fig. 2) and riverbed biotopes/habitats variability from its springs to the confluence with the Olt River.

The Olteţ Basin shelter also some of the oldest (Quaternary) prehistoric man tools in the Romanian territory (Pebble-Culture) (Mutihac, 1990), the continuous presence of man in this basin being reflected mostly due to the later human developments.

The mountainous sector (0) with crystalline schists, volcanic and calcareous rocks, is characterized by a typical mountainous lotic habitats with steep slopes, deepened and accentuated "V" and " $\mathrm{U}$ " profiles of the valley, big stones in the riverbed, waterfalls, and very fast flowing water. The Jurassic calcareous massif in the northern proximity of Polovragi locality, allows for the possibility of this river to cut one of the most spectacular gorges in the Carpathians, the "Cheile Olteţului"/“"Olteţului Gorge" (Ujvári, 1972).

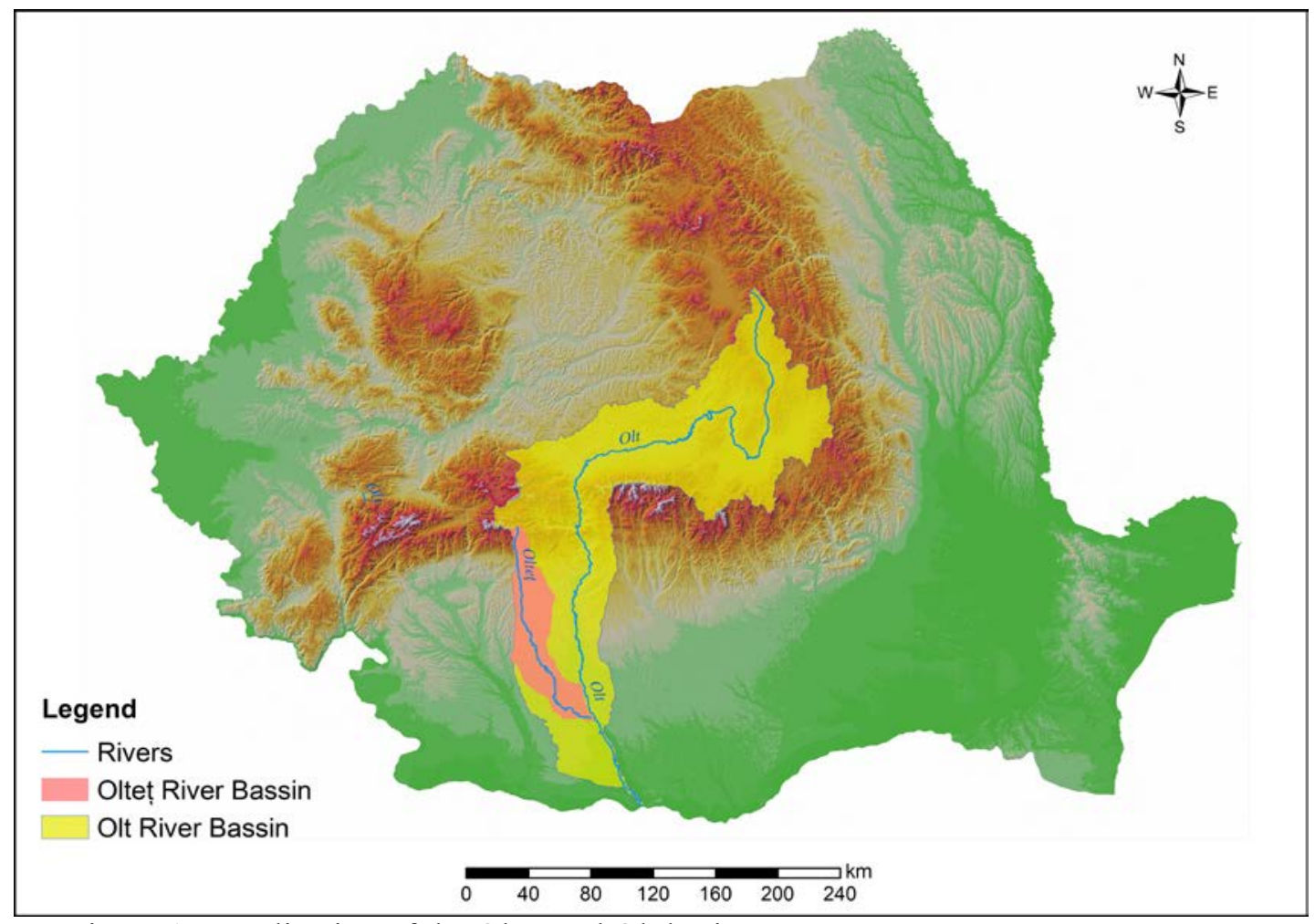

Figure 1: Localization of the Olteţ and Olt basins, in the Romanian national territory. 




Figure 2: Relief units and sampling ststions in the the Olteţ River basin area. 
Downstream the "Cheile Olteţului"/"Olteţului Gorge", the river passes the subcarpathian Polovragi Depression/Depresiunea Polovragi sector (2), with Meotian clay in the geological substrate (Tufescu, 1966), and boulders and stones in the riverbed due to the continuous erosion and transport of these materials from the upper near mountain sector of the valley. The "V/U" shaped valley still allows the water to flow fast.

Downstream the subcarpathian Polovragi Depression the valley passes on to the Getic Depression/Depresiunea Getică sector (3); the river eroded a big gravel geological substratum known as "Pietrișuri de Cândești"/“Cândești Gravels" and deposited there in a lotic-lenitic regime (Roșu, 1973). The river is in a submountainous (fast velocity) regime.

Downstream, the river passes through the unit named Getic Piedmont/Piemontul Getic sector (4). Characterized by gravels, sands and in some sectors, conglomerates, (Tufescu, 1966), the water flow speed becomes moderate.

The final sector of the Olteţ River, before its confluence with the Olt River and, in the proximity of Fălcoiu Commune, is a plain relief belonging to the Romanian Plain/Câmpia Română sector (5). Characterized by Pliocen and Cuaternary, old sedimentary sands, gravels, clay and loess, the water flow speed becomes low, even stagnant in some areas near banks.

\section{MATERIALS AND METHODS}

This ichthyological study was realized on the whole $175 \mathrm{~km}$ length of the Oltet River, from its mountainous area to the confluence with the Olt River, in 2011-2012.

The distances between two consecutive sampling stations where around between one to three and a half km, 56 sampling stations (55 quantitative and one qualitative) were done.

The fishing method which was used was the electrofishing in time/effort unit (30 minutes). The device which was used was an Aquatech IG 600, $30 \mathrm{~A}, 0.65 / 1.2 \mathrm{kw}$, with two net stopers. All the sampled fish were identified, counted and released immediately in situ.

For the fish associations, localization was used a "Garmin GPS map 62s".

The Carpathian Fish Index of Biotic Integrity (CF-IBI) (Bănăduc and CurteanBănăduc, 2002) was used in discriminating human induced degradation effects on ichthyofauna integrity, based on life history and feeding relationships selected metrics.

\section{RESULTS}

(1 The most upper Olteţ River area, in the mountainous sector, from its springs to the exit of the "Olteţului Gorge"/“Cheile Olteţului" belongs to the upper trout zone $\left(\mathrm{O}_{1}\right.$ $\mathrm{O}_{13}$ ). Here only Salmo trutta fario (Tab. 1) individuals were sampled, the explanation being based on the habitat characteristics like rapids, waterfalls, stony river bed, "V" shaped slopes, etc., belonging to two mountainous relief units namely Parâng and Căpățânii mountains (Figs. 2, 3 and 4). Despite the valley being very narrow, there are few small lateral natural water accumulations (Fig. 5), with their permanent springs or formed by small tributaries in which fish associations of Phoxinus phoxinus and Squalius cephalus are present. The CF-IBI 45 score on the river reflects exceptional assemblage of fish species, comparable to pristine areas. The individual trout numbers and the presence of all age classes in the sampling sections reveal an excellent state of the river. The lower number of individuals in the station $\mathrm{O}_{13}$ can be explained by the fact that sometimes at low water levels, the riverbed dries out completely and the water sometimes will flow only underground through a well developed carstic substrata. The very difficult accessibility to the river due to high and steep slopes results in very low human impact which therefore induces an excellent state fish fauna. 


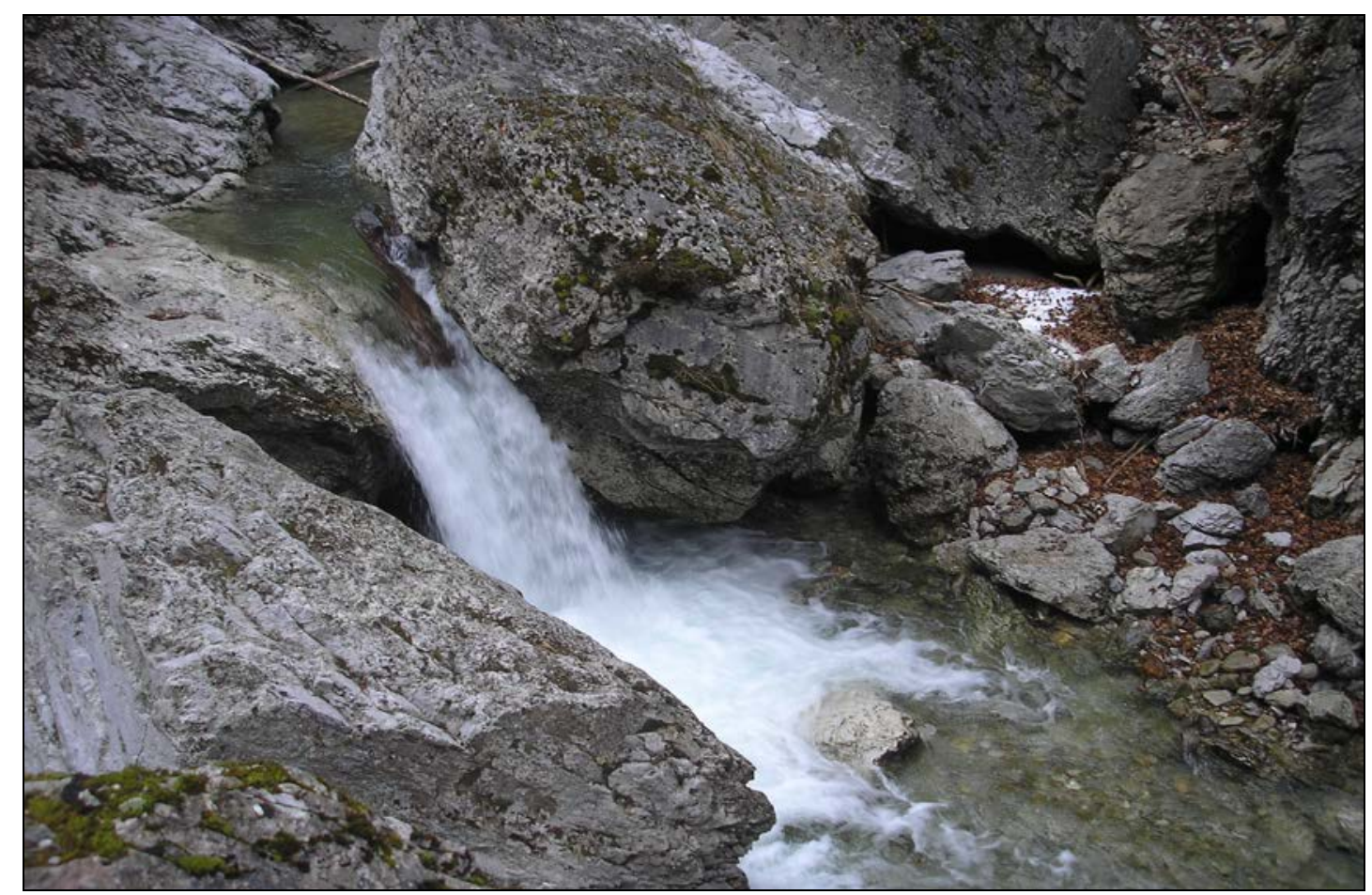

Figure 3: Mountainous rocky stream sector characteristic habitat.

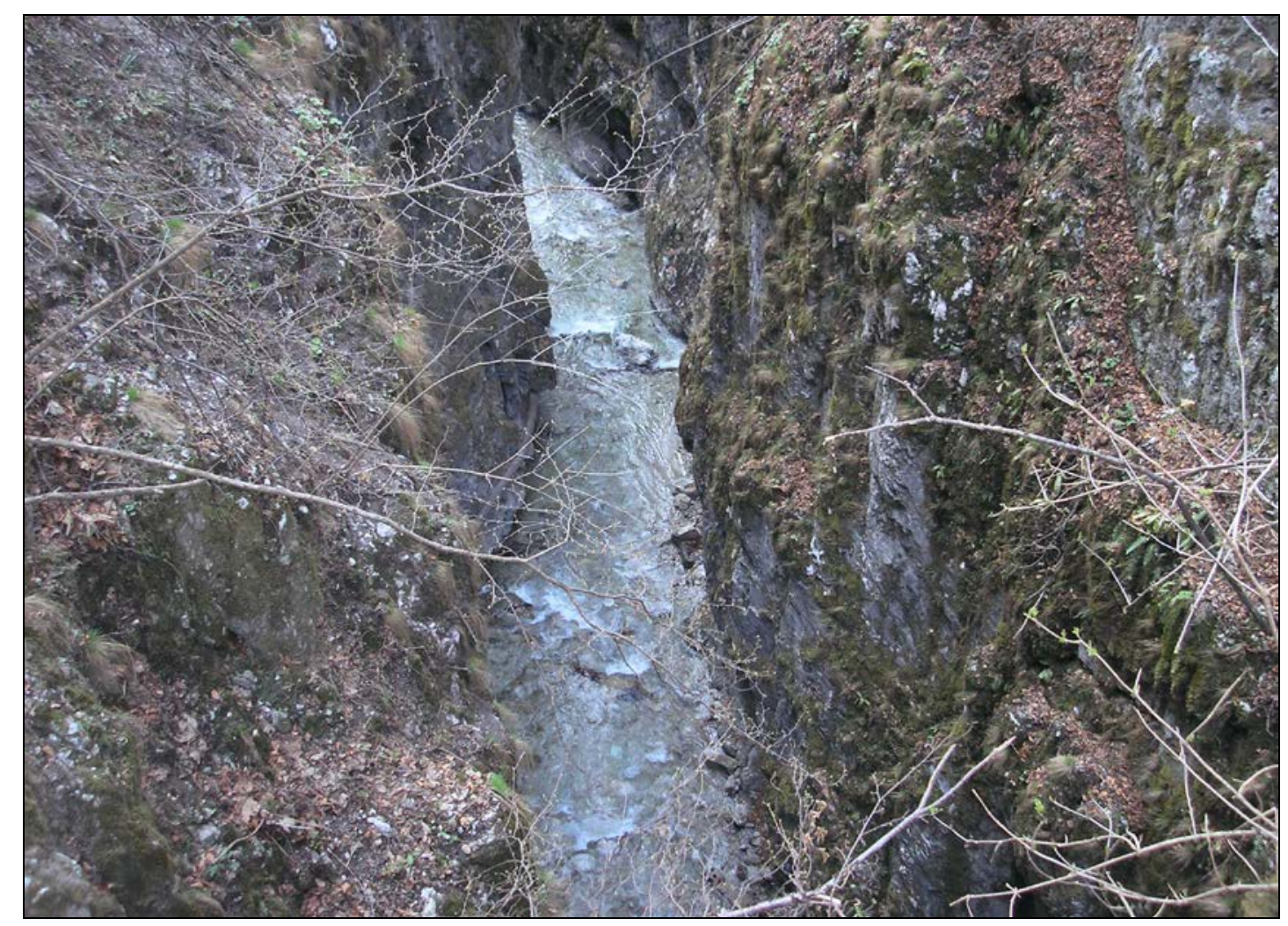

Figure 4: Olteţ Valley steep "V/U” shape slopes in the Cheile Olteţului/Olteţului Gorge. 
Table 1: The upper trout zone area of Olteţ River $\left(\mathrm{O}_{1}-\mathrm{O}_{7}\right)$; Salmo trutta fario - S.t.f.

\begin{tabular}{|c|c|c|c|c|}
\hline $\begin{array}{c}\text { Sampling } \\
\text { stations }\end{array}$ & $\begin{array}{c}\text { Sampling station localization and } \\
\text { description }\end{array}$ & Species & $\begin{array}{l}\text { Number of } \\
\text { individuals }\end{array}$ & $\begin{array}{l}\text { Abundance } \\
\text { (\%) }\end{array}$ \\
\hline $\mathrm{O}_{1}$ & $\begin{array}{l}\mathrm{N}-45.3314 \\
\mathrm{E}-23.7903 \\
5 \mathrm{~km} \text { upstream the confluence with } \\
\text { Ungurelul tributary. Riverbed length } \\
\text { maximum } 3.1 \mathrm{~m} \text { and minimum } 2.1 \mathrm{~m} . \\
\text { Maximum water depth } 13 \mathrm{~cm} .\end{array}$ & S.t.f. & 30 & 100 \\
\hline $\mathrm{O}_{2}$ & $\begin{array}{l}\mathrm{N}-45.3230 \\
\mathrm{E}-23.7939 \\
4 \mathrm{~km} \text { upstream the confluence with } \\
\text { Ungurelul tributary. Riverbed length } \\
\text { maximum } 3.3 \mathrm{~m} \text { and minimum } 2.2 \mathrm{~m} \text {. } \\
\text { Maximum water depth of } 14 \mathrm{~cm} .\end{array}$ & S.t.f. & 42 & 100 \\
\hline $\mathrm{O}_{3}$ & $\begin{array}{l}\mathrm{N}-45.3061 \\
\mathrm{E}-23.7907 \\
3 \mathrm{~km} \text { upstream the confluence with } \\
\text { Ungurelul tributary. Riverbed length } \\
\text { maximum } 3.3 \mathrm{~m} \text { and minimum } 3.1 \mathrm{~m} \text {. } \\
\text { Maximum water depth of } 21 \mathrm{~cm} \text {. }\end{array}$ & S.t.f. & 73 & 100 \\
\hline $\mathrm{O}_{4}$ & $\begin{array}{l}\mathrm{N}-45.3139 \\
\mathrm{E}-23.7907 \\
2 \mathrm{~km} \text { upstream the confluence with } \\
\text { Ungurelul tributary. Riverbed length } \\
\text { maximum } 4.1 \mathrm{~m} \text { and minimum } 2.9 \mathrm{~m} \text {. } \\
\text { Maximum water depth of } 25 \mathrm{~cm} .\end{array}$ & S.t.f. & 68 & 100 \\
\hline $\mathrm{O}_{5}$ & $\begin{array}{l}\mathrm{N}-45.2971 \\
\mathrm{E}-23.7868 \\
1 \mathrm{~km} \text { upstream the confluence with } \\
\text { Ungurelul tributary. Riverbed length } \\
\text { maximum } 4.9 \mathrm{~m} \text { and minimum } 3.1 \mathrm{~m} \text {. } \\
\text { Maximum water depth of } 32 \mathrm{~cm} \text {. }\end{array}$ & S.t.f. & 99 & 100 \\
\hline $\mathrm{O}_{6}$ & $\begin{array}{l}\mathrm{N}-45.2901 \\
\mathrm{E}-23.7788 \\
\text { Downstrean the confluence of Olteţ } \\
\text { and Ungurelul rivers. Riverbed length } \\
\text { maximum } 5.2 \mathrm{~m} \text { and minimum } 3.6 \mathrm{~m} \text {. } \\
\text { Maximum water depth } 33 \mathrm{~cm} \text {. }\end{array}$ & S.t.f. & 33 & 100 \\
\hline $\mathrm{O}_{7}$ & $\begin{array}{l}\mathrm{N}-45.2717 \\
\mathrm{E}-23.7705 \\
1 \mathrm{~km} \text { downstrean the confluence of } \\
\text { Olteţ and Ungurelul rivers. Riverbed } \\
\text { length maximum } 8.4 \mathrm{~m} \text { and minimum } \\
4.9 \mathrm{~m} \text {. Maximum water depth } 39 \mathrm{~cm} \text {. }\end{array}$ & S.t.f. & 82 & 100 \\
\hline
\end{tabular}


Table 1 (continuing): The upper trout zone area of Olteţ River $\left(\mathrm{O}_{8}-\mathrm{O}_{13}\right)$; Salmo trutta fario - S.t.f.

\begin{tabular}{|c|c|c|c|c|}
\hline $\begin{array}{l}\text { Sampling } \\
\text { stations }\end{array}$ & $\begin{array}{c}\text { Sampling station localization and } \\
\text { description }\end{array}$ & Species & $\begin{array}{l}\text { Number of } \\
\text { individuals }\end{array}$ & $\begin{array}{l}\text { Abundance } \\
\text { (\%) }\end{array}$ \\
\hline $\mathrm{O}_{8}$ & $\begin{array}{l}\mathrm{N}-45.2609 \\
\mathrm{E}-23.7707 \\
2 \mathrm{~km} \text { downstrean the confluence of } \\
\text { Olteţ and Ungurelul rivers. Riverbed } \\
\text { length maximum } 9.3 \mathrm{~m} \text { and } \\
\text { minimum } 7.6 \mathrm{~m} \text {. Maximum water } \\
\text { depth } 45 \mathrm{~cm} \text {. }\end{array}$ & S.t.f. & 60 & 100 \\
\hline $\mathrm{O}_{9}$ & $\begin{array}{l}\mathrm{N}-45.2536 \\
\mathrm{E}-23.7667 \\
3 \mathrm{~km} \text { downstrean the confluence of } \\
\text { Olteţ and Ungurelul rivers. Riverbed } \\
\text { length maximum } 9.9 \mathrm{~m} \text { and } \\
\text { minimum } 7.8 \mathrm{~m} \text {. Maximum water } \\
\text { depth } 43 \mathrm{~cm} \text {. }\end{array}$ & S.t.f. & 71 & 100 \\
\hline $\mathrm{O}_{10}$ & $\begin{array}{l}\mathrm{N}-45.2449 \\
\mathrm{E}-23.7654 \\
4 \mathrm{~km} \text { downstrean the confluence } \\
\text { of Oltet and Ungurelul rivers. } \\
\text { Riverbed length maximum } 9.5 \mathrm{~m} \text { and } \\
\text { minimum } 7.4 \mathrm{~m} \text {. Water maximum } \\
\text { depth } 44 \mathrm{~cm} \text {. }\end{array}$ & S.t.f. & 51 & 100 \\
\hline $\mathrm{O}_{11}$ & $\begin{array}{l}\mathrm{N}-45.2364 \\
\mathrm{E}-23.7702 \\
5 \mathrm{~km} \text { downstrean the confluence } \\
\text { of Oltet and Ungurelul rivers. } \\
\text { Riverbed length maximum } 7.3 \mathrm{~m} \text { and } \\
\text { minimum } 5.1 \mathrm{~m} \text {. Maximum water } \\
\text { depth } 60 \mathrm{~cm} \text {. }\end{array}$ & S.t.f. & 59 & 100 \\
\hline $\mathrm{O}_{12}$ & $\begin{array}{l}\mathrm{N}-45.2280 \\
\mathrm{E}-23.7698 \\
6 \mathrm{~km} \text { downstrean the confluence of } \\
\text { Olteţ and Ungurelul rivers. Riverbed } \\
\text { length maximum } 1.2 \mathrm{~m} \text { and } \\
\text { minimum } 8.5 \mathrm{~m} \text {. Maximum water } \\
\text { depth } 24 \mathrm{~cm} \text {. }\end{array}$ & S.t.f. & 61 & 100 \\
\hline $\mathrm{O}_{13}$ & $\begin{array}{l}\mathrm{N}-45.2190 \\
\mathrm{E}-23.7725 \\
7 \mathrm{~km} \text { downstrean the confluence } \\
\text { of Oltet and Ungurelul rivers. } \\
\text { Riverbed length maximum } 8 \mathrm{~m} \text { and } \\
\text { minimum } 4.2 \mathrm{~m} \text {. Maximum water } \\
\text { depth } 80 \mathrm{~cm} \text {. }\end{array}$ & S.t.f. & 15 & 100 \\
\hline
\end{tabular}




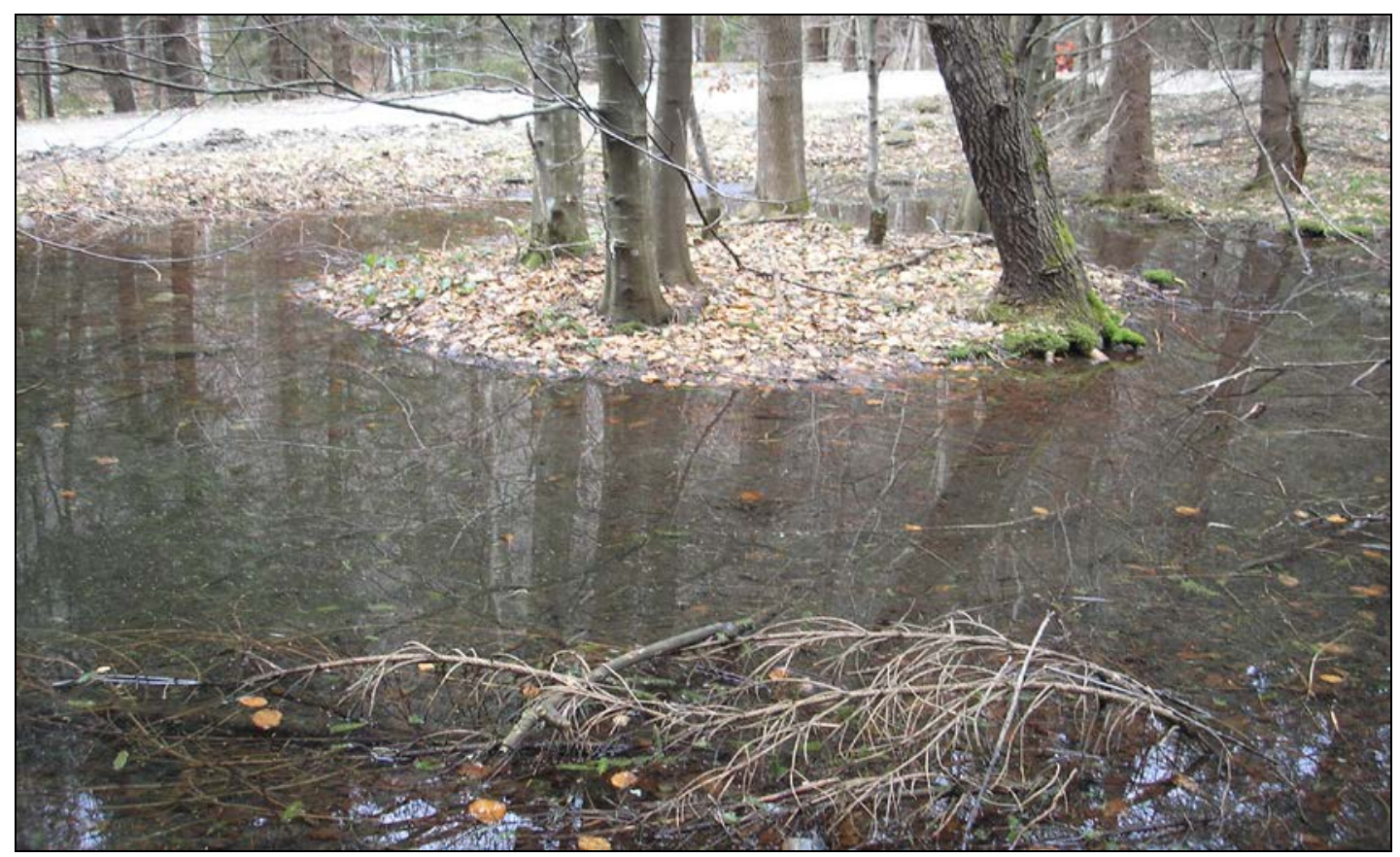

Figure 5: Small natural lateral water accumulation in the Olteţ upper basin.

2 Downstream the "Olteţului Gorge", where the river passes in the subcarpathian Polovragi Depression sector $\left(\mathrm{O}_{14}-\mathrm{O}_{16}\right)$, is the lower trout zone, and Salmo trutta fario remains dominant with a decreasing trend to the lower sectors, but still influence the downstream zone due to the excellent state of the ichthyofauna in the mountainous area.

The upper part $\left(\mathrm{O}_{14}-\mathrm{O}_{15}\right)$ is in a natural mountain-submontane transition condition (CF-IBI 45) regarding the present habitats (Figs. 6 and 7), reflected in a high number of trouts (Tab. 2). In $\mathrm{O}_{16}$ sector near Polovragi Commune, due to a chaotic exploitation of the riverbed minerals (Fig. 8), the CF-IBI score is 2 and reflects extreme few species and individuals present; tolerant species being dominant. The Salmo trutta fario disappeared and only few Orthrias barbatulus individuals were sampled in small lateral artificial cavities in the left riverbed/banks area (Fig. 9) that remained after the riverbed exploitation activities. The persistence of this species here is problematic due to aggressive human impact.

A large dam (Fig. 10) is near Polovragi Commune, in Polovragi Depression $\left(\mathrm{O}_{17}\right)$. A dam which deflects in a subterranean large pipe where the majority of the water flows for a series of two medium size downstream hydro power plants; sometimes in the summer and autumn the dam deflects all the water into this pipe (Fig. 11). Downstream the dam and due to the significant habitats modification, it appears as Phoxinus phoxinus is the dominant species, followed by Salmo trutta fario and accidentally Barbus meridionalis (Tab. 2). The CF-IBI score (27) reveals some expected species are rare and tolerant species as dominant.

On the $\mathrm{O}_{18}$ sector the river passes in a new relief unit type (Mateești and Sârbești hills area). The near upstream dam is a negative influence and downstream there is the appearance of more types of human impact categories (riverbed minerals overexploitation till the clay substratum (Figs. 12 and 13), affecting the macroinvertebrates food of fish; the pollution from mineral exploitations; roads presence in the riverbed (Fig. 14); and a two $\mathrm{m}$ high barrage (Fig. 15) with no fish leather which interrupt the fish populations connectivity), diminishing the river quality; till Ciupercenii de Olteţ locality CF-IBI value is only 2. 


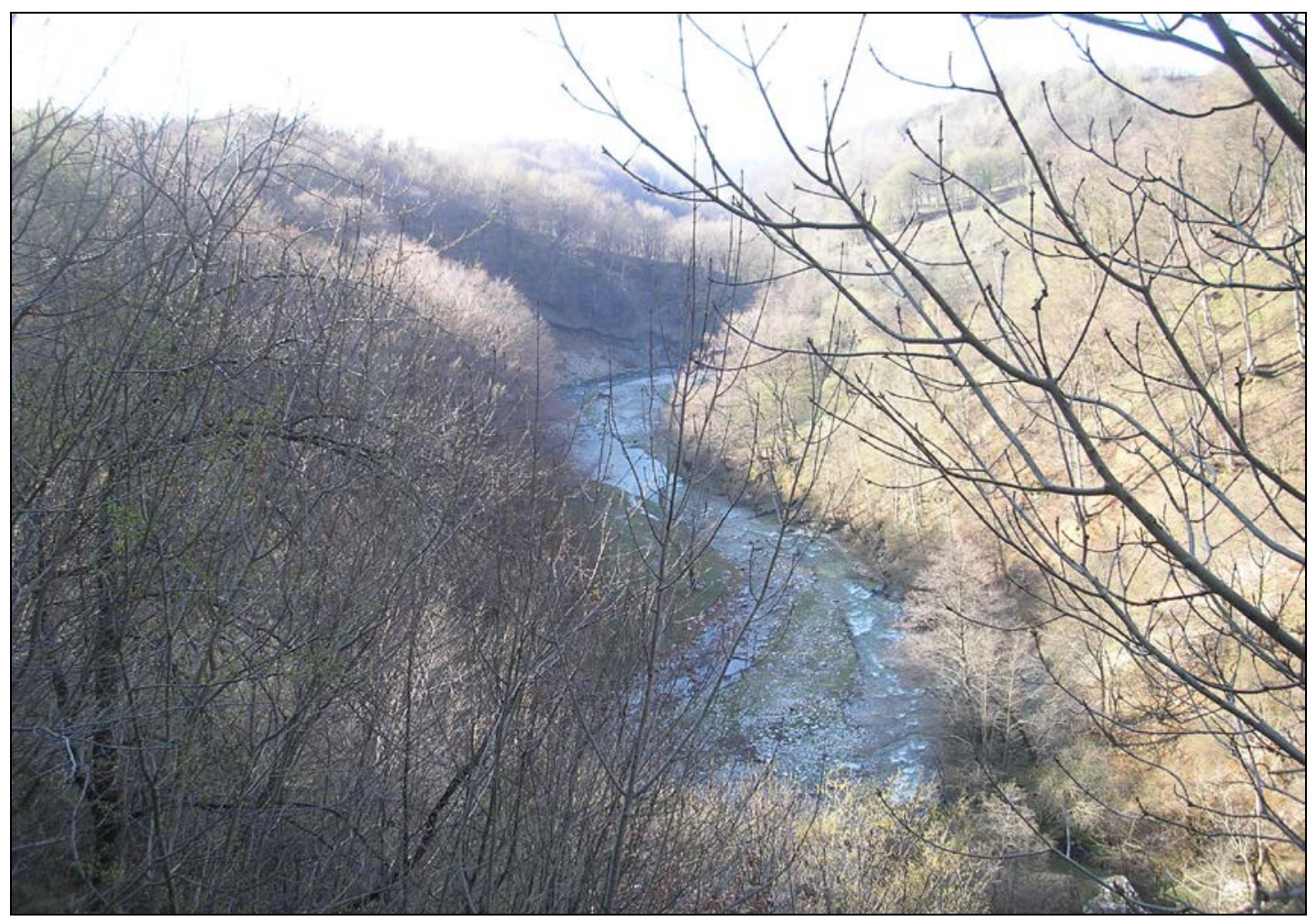

Figure 6: The Olteţ River valley at the entrance in the Polovragi Depression.

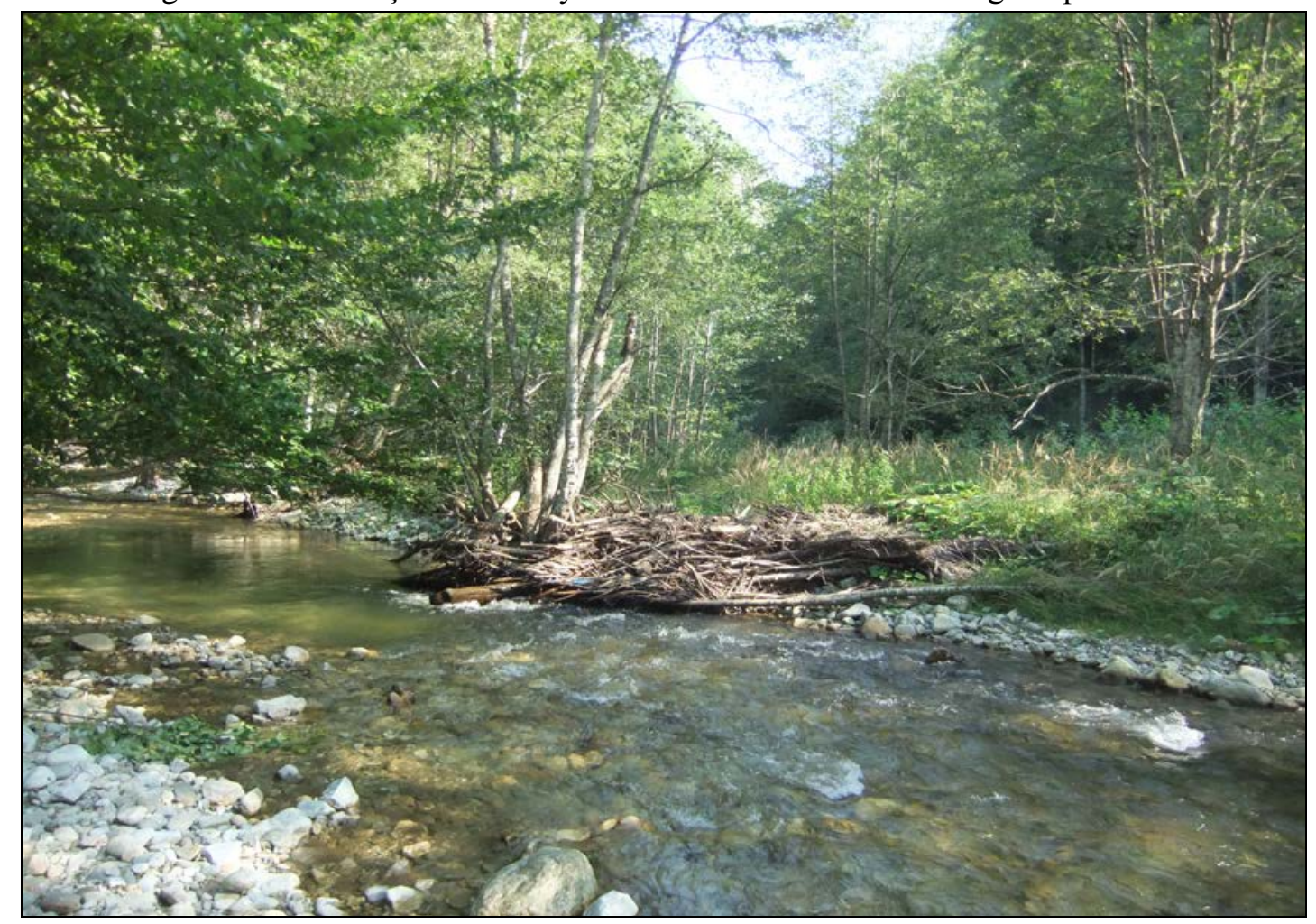

Figure 7: Natural lotic habitat in the upper sector of Polovragi Depression. 
Table 2: The sampled fish material, in the lower trout zone area of Olteţ River $\left(\mathrm{O}_{14}-\mathrm{O}_{18}\right)$; Salmo trutta fario - S.t.f.; Phoxinus phoxinus - P.p.; Orthrias barbatulus - O.b.; Barbus meridionalis - B.m.

\begin{tabular}{|c|c|c|c|c|}
\hline $\begin{array}{c}\text { Sampling } \\
\text { stations }\end{array}$ & $\begin{array}{c}\text { Sampling station localization and } \\
\text { description }\end{array}$ & Species & $\begin{array}{l}\text { Number of } \\
\text { individuals }\end{array}$ & $\begin{array}{c}\text { Abundance } \\
\text { (\%) }\end{array}$ \\
\hline $\mathrm{O}_{14}$ & $\begin{array}{l}\mathrm{N}-45.2029 \\
\mathrm{E}-23.7807 \\
8 \mathrm{~km} \text { downstrean the confluence of } \\
\text { Oltet and Ungurelul rivers. } 200-300 \mathrm{~m} \\
\text { downstream the Cheile Olteţului } \\
\text { Gorge. Riverbed length maximum } 8 \mathrm{~m} \\
\text { and minimum } 4 \mathrm{~m} \text {. Maximum water } \\
\text { depth } 100 \mathrm{~cm} \text {. }\end{array}$ & S.t.f. & 66 & 100 \\
\hline $\mathrm{O}_{15}$ & $\begin{array}{l}\mathrm{N}-45.1836 \\
\mathrm{E}-23.7859 \\
9 \mathrm{~km} \text { downstrean the confluence of } \\
\text { Olteţ and Ungurelul rivers. } 1 \mathrm{~km} \\
\text { downstream the Cheile Olteţului } \\
\text { Gorge. Riverbed length maximum } 8 \mathrm{~m} \\
\text { and minimum } 4 \mathrm{~m} \text {. Maximum water } \\
\text { depth } 100 \mathrm{~cm} \text {. }\end{array}$ & S.t.f. & 83 & 100 \\
\hline $\mathrm{O}_{16}$ & $\begin{array}{l}\mathrm{N}-45.1792 \\
\mathrm{E}-23.7856 \\
10 \mathrm{~km} \text { downstrean the confluence of } \\
\text { Olteţ and Ungurelul rivers. } 2 \mathrm{~km} \\
\text { downstream the Cheile Olteţului } \\
\text { Gorge. Riverbed length maximum } 8 \mathrm{~m} \\
\text { and minimum } 4 \mathrm{~m} \text {. Maximum water } \\
\text { depth } 100 \mathrm{~cm} \text {. }\end{array}$ & O.b. & 5 & 100 \\
\hline $\mathrm{O}_{17}$ & $\begin{array}{l}\mathrm{N}-45.1555 \\
\mathrm{E}-23.7905 \\
1 \mathrm{~km} \text { downstrean the dam and } 10 \mathrm{~km} \\
\text { downstream the sonfluence of Olteț } \\
\text { and Ungurelul rivers. } 3 \mathrm{~km} \\
\text { downstream the Cheile Olteţului } \\
\text { Gorge. Riverbed length maximum } 8 \mathrm{~m} \\
\text { and minimum } 4 \mathrm{~m} \text {. Maximum water } \\
\text { depth } 100 \mathrm{~cm} \text {. }\end{array}$ & $\begin{array}{l}\text { S.t.f. } \\
\text { P.p. } \\
\text { B.m. }\end{array}$ & $\begin{array}{c}23 \\
55 \\
1\end{array}$ & $\begin{array}{c}29.11 \\
69.62 \\
1.26\end{array}$ \\
\hline $\mathrm{O}_{18}$ & $\begin{array}{l}\mathrm{N}-45.1387 \\
\mathrm{E}-23.7931 \\
2 \mathrm{~km} \text { downstrean the dam and } 11 \mathrm{~km} \\
\text { downstream the sonfluence of Olteţ and } \\
\text { Ungurelul rivers. } 4 \mathrm{~km} \text { downstream the } \\
\text { Cheile Olteţului Gorge. Riverbed } \\
\text { length maximum } 8 \mathrm{~m} \text { and minimum } 4 \\
\text { m. Maximum water depth } 100 \mathrm{~cm} \text {. }\end{array}$ & B.m. & 3 & 100 \\
\hline
\end{tabular}




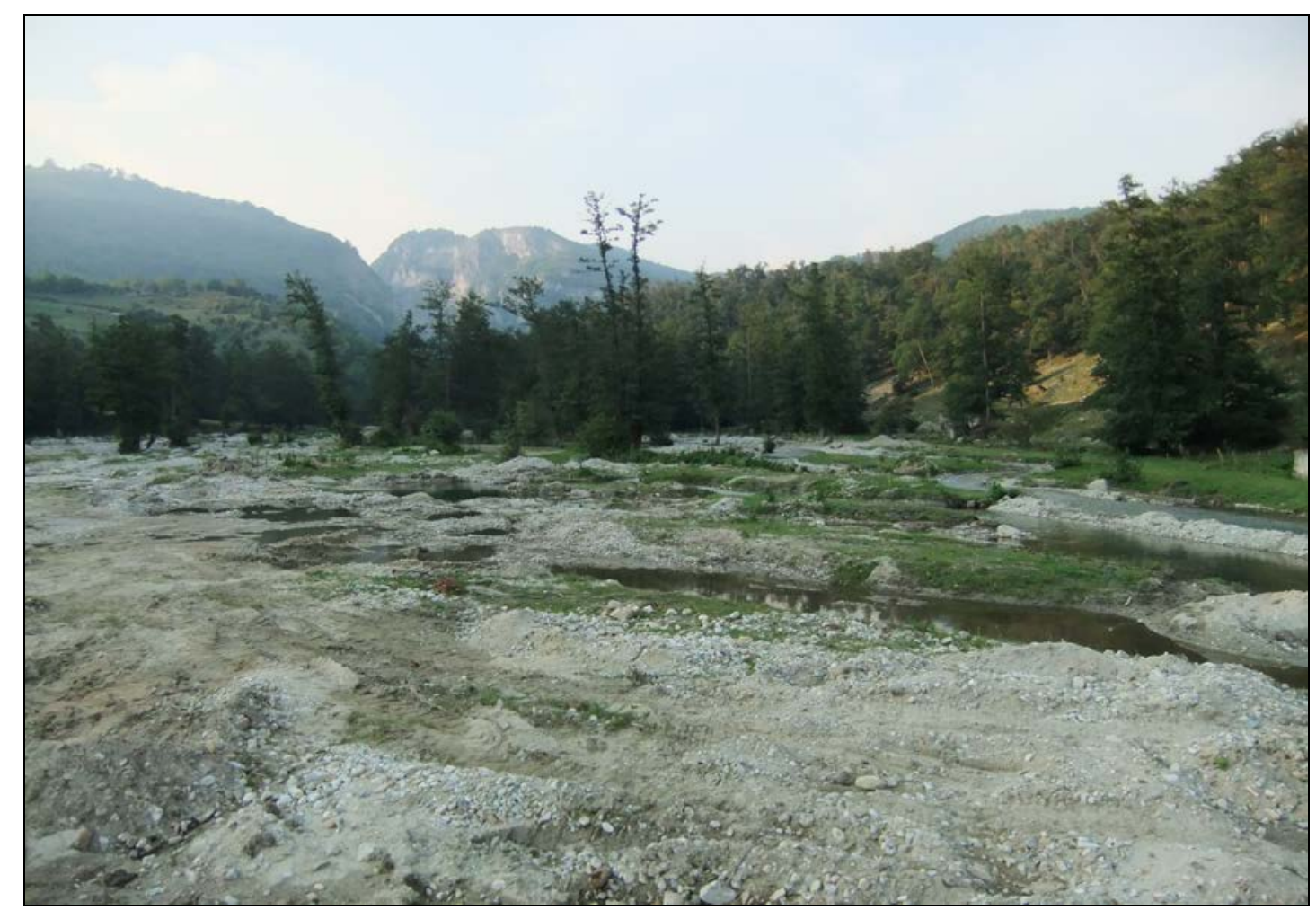

Figure 8: Disturbed lotic habitat due to the local riverbed minerals chaotic exploitation.

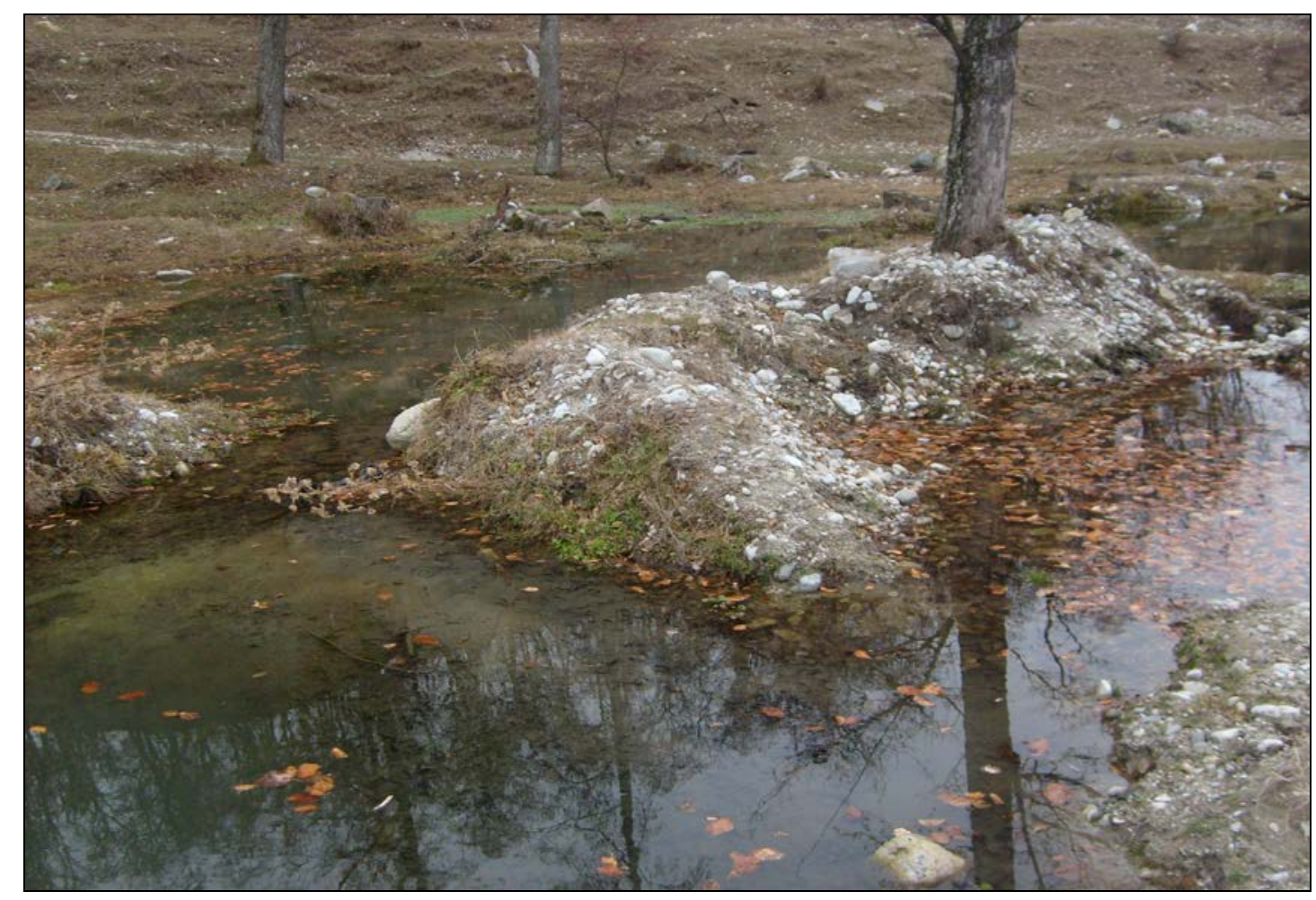

Figure 9: Artificial cavity where few Orthrias barbatulus were sampled. 


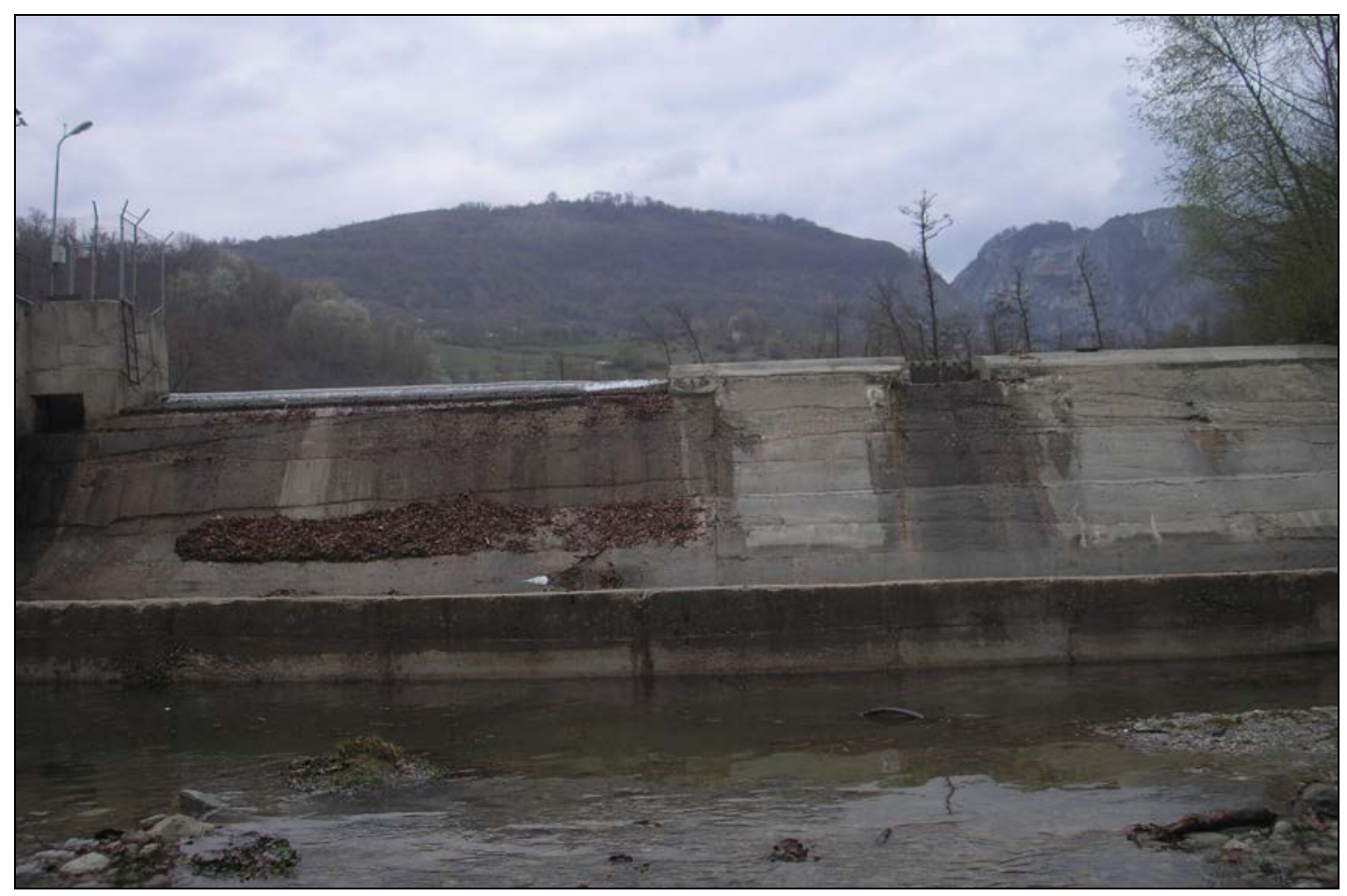

Figure 10: The dam fragmented this rivers sector lotic continuum.

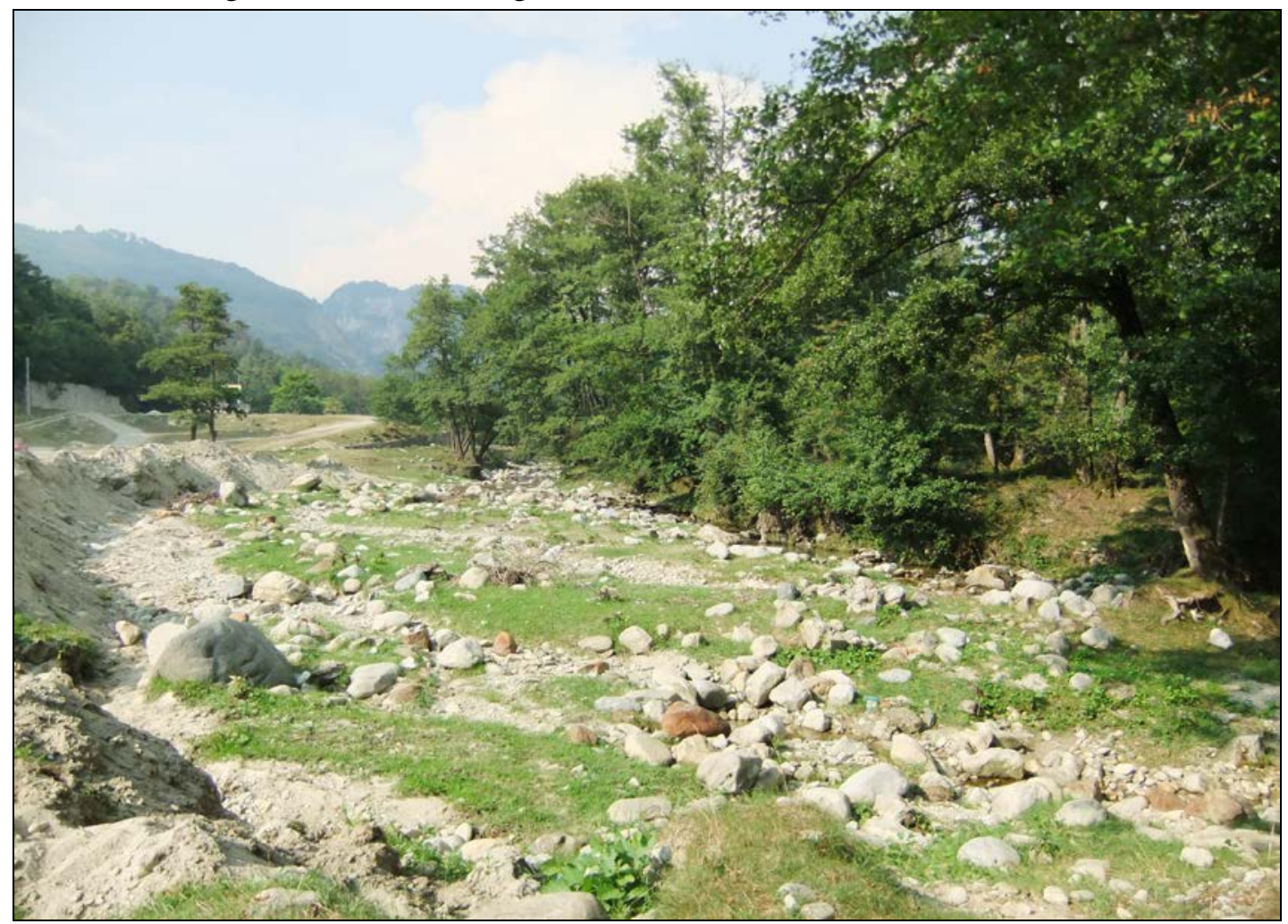

Figure 11: Almost drought riverbed downstream the dam. 


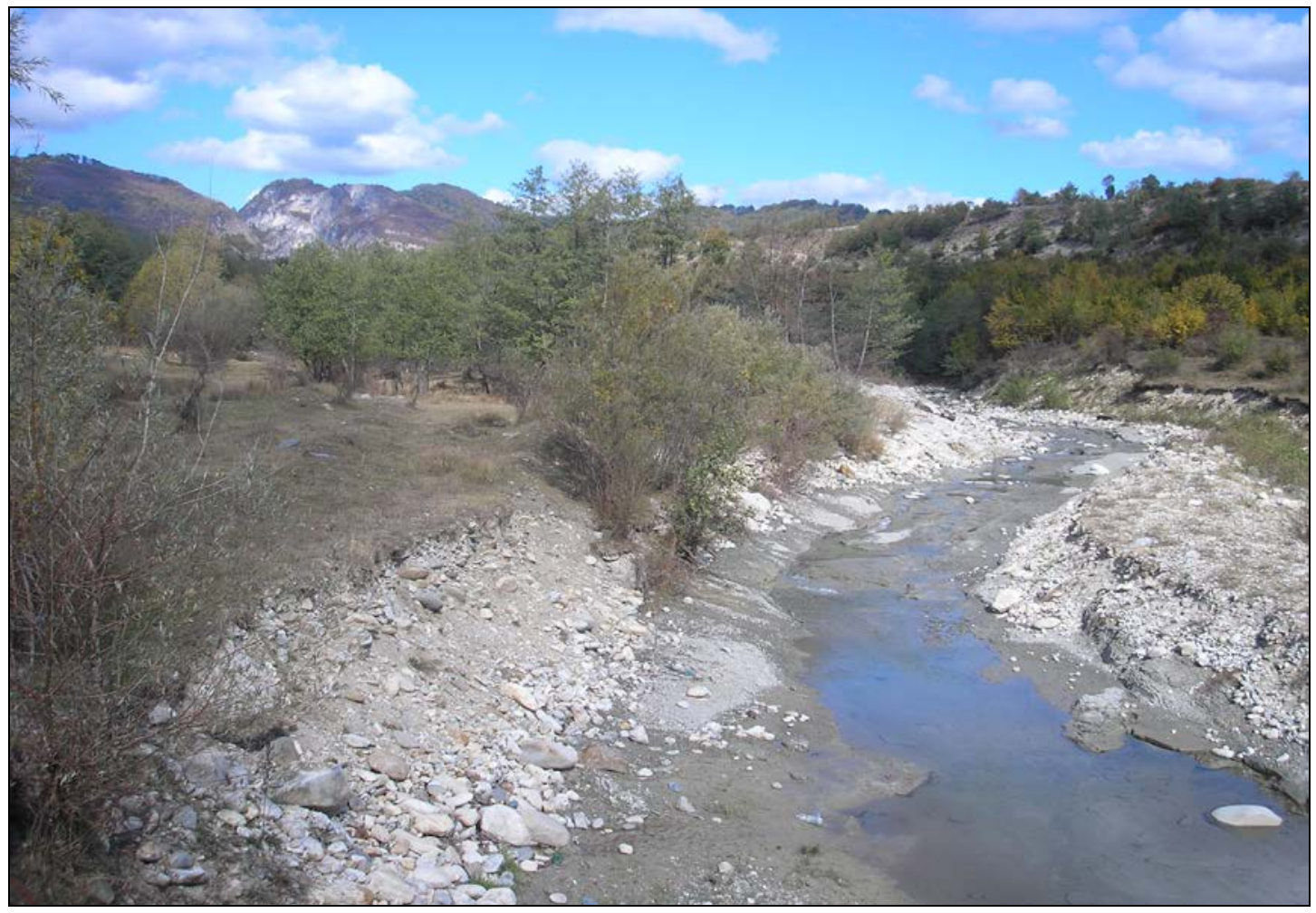

Figure 12: Clay river substratum with no more sand, gravels and boulders.

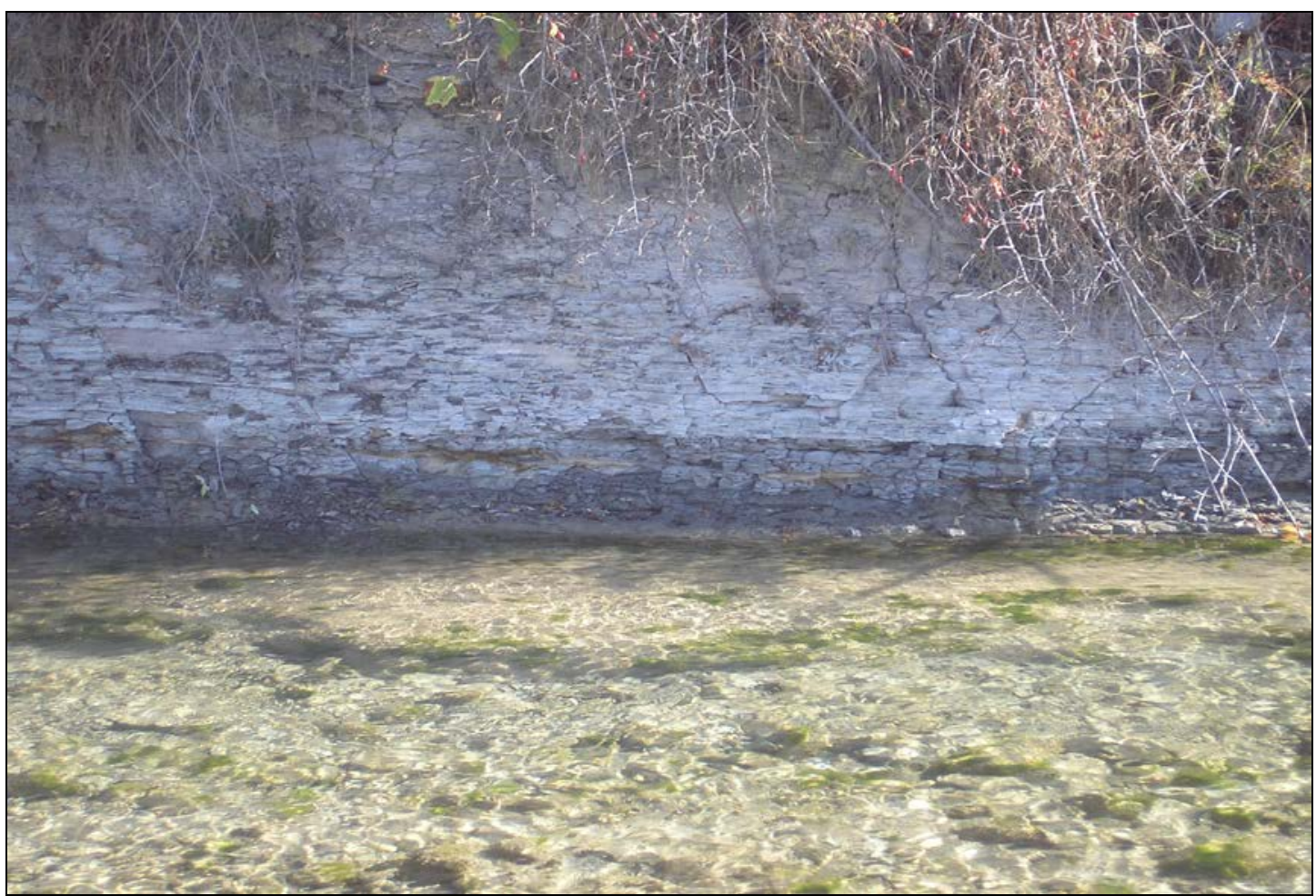

Figure 13: Clay substratum and erosion on riverbed after mineral overexploitation. 


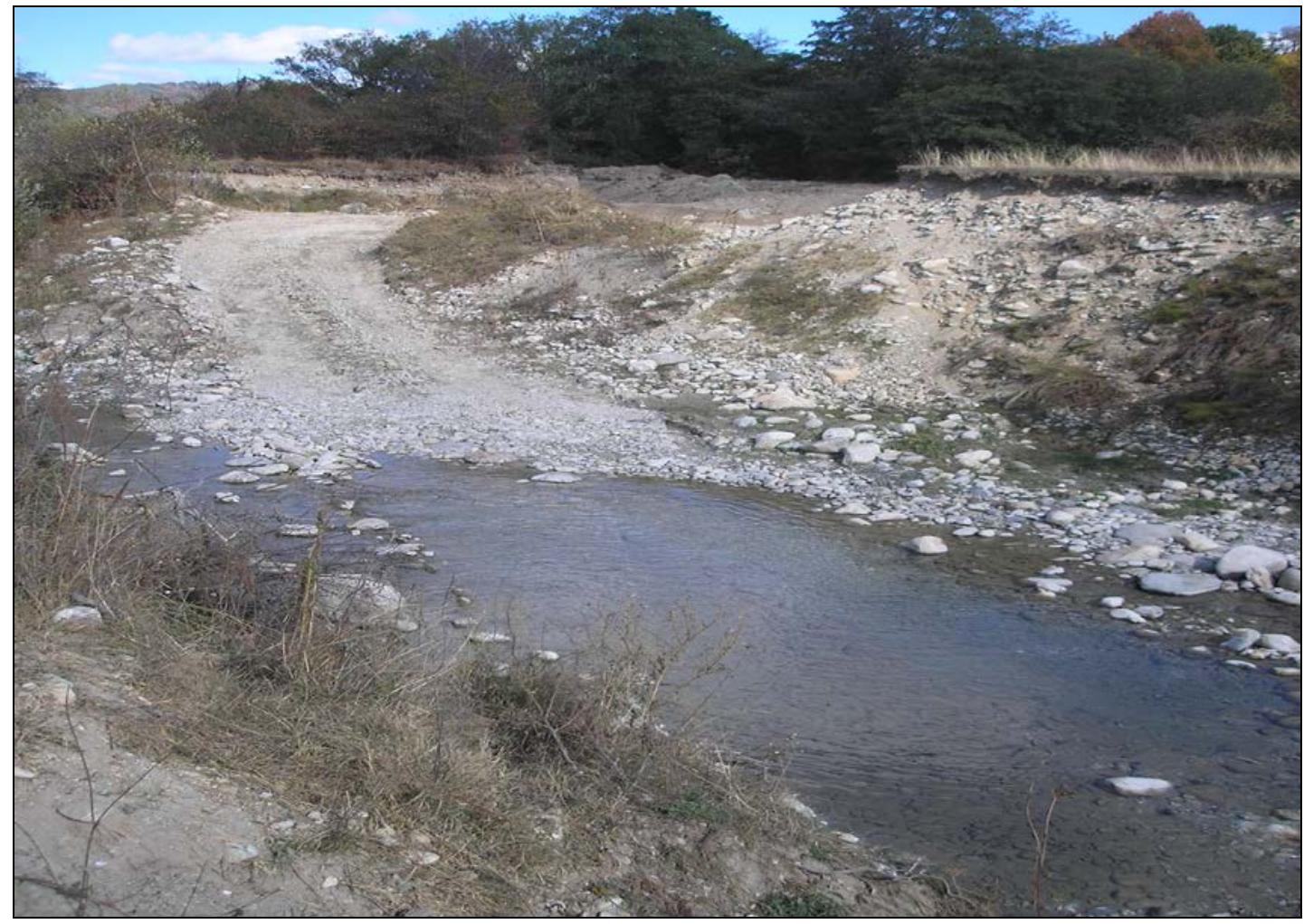

Figure 14: Road in the riverbed.

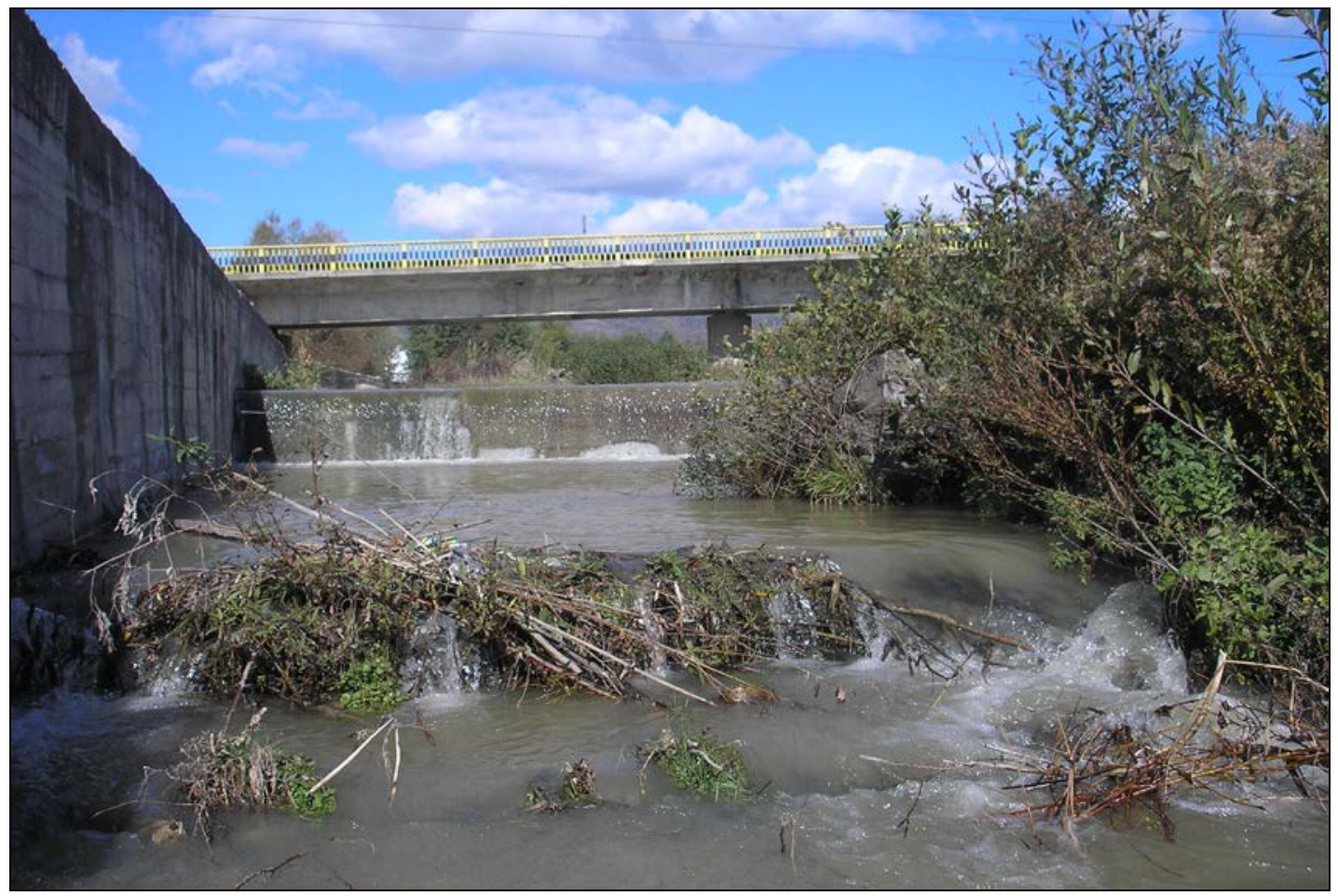

Figure 15: Concrete barrage with no fish leather. 
A pre-Common nase zone is present. Due to complex, significant and continuous human impact on this depression area, the Grayling and Meridional Barbel ichthyological zone is not present. A lot of species characteristic for this ichthyological zone in Romanian Carpathians (Bănărescu, 1964) are missing (Thymallus thymallus, Cottus gobio, Alburnoides bipunctatus, Cobitis romanica, Cobitis aurata) and the present ones are there in short sectors and with a relatively low number of individuals (Phoxinus phoxinus, Orthrias barbatulus - accidental, Barbus meridionalis - accidental). The only three juveniles of Barbus meridionalis sampled in the lower sector of this depression area reveal also a very low ecological status of the ichthyofauna. This depression area fish fauna conservation status decreases significantly from its excellent status in its upper zone, to average/low in its middle zone, to very bad conservation status in its lower zone, due to the human impact effects.

3 The Podişul Getic - northern sector, can be considered as being from the ichthyological point of view in majority to the Common nase zone as a continuity of the upper pre-Common nase zone, with the exception of the first sampling stations $\left(\mathrm{O}_{19}-\mathrm{O}_{23}\right)$, which are in the Grayling and Mediterranean barbell zone influence, but also represent a transition zone to the next ichthyological zone; this is the first appearance of the Alburnoides bipunctatus and Squalius cephalus species. The upper diverse and high human impact presence induces an obvious fish fauna destructuring and a strong deviation of transition of ichthyofauna from the natural similar lotic sectors. After the recovering of all the water flow from the upstream two medium size power plants subterranean pipes, with a general substratum with boulders but also small patches with gravel, sand or even clay, the downstream lotic habitats can be considered as becoming again typical for this ichthyological zone, in conformity with Bănărescu zonation (1964). Excepting the Chondrostoma nasus whose absence is not clear as a natural one or rather induced by the human impact, the fish associations' structure reveal the presence of its ichthyological zone.

Table 3a: The sampled fish material, in the pre-Common nase zone area of Olteţ River $\left(\mathrm{O}_{19}-\mathrm{O}_{23}\right)$; Phoxinus phoxinus - P.p.; Barbus meridionalis - B.m.; Alburnoides bipunctatus - A.b.; Squalius cephalus - S.c.; Orthrias barbatulus - O.b.; maximum riverbed length - max.r.l., minimum riverbed length - min.r.l., maximum water depth - max.w.d.

\begin{tabular}{|l|l|c|c|c|}
\hline \multirow{2}{*}{$\mathrm{O}_{19}$} & N - 45.1309, E - 23.7926, max.r.l. - 15 m, min.r.l. & \multirow{2}{*}{ P.p. } & 2 & $22.22 \%$ \\
& - 5.5 m, max.w.d. - 1.5 m S. 14 (Ciupercienii de & B.m. & 7 & $77.77 \%$ \\
& Oltet aval de pragurile de beton) & & \\
\hline \multirow{2}{*}{$\mathrm{O}_{20}$} & N - 45.1196, E - 23.7939, max.r.l. - 9 m, min.r.l. - & P.p. & 26 & $41.93 \%$ \\
& 6 m, max.w.d. - 80 cm S. 15 (Sârbești) & A.b. & 34 & $54.83 \%$ \\
& & B.m. & 2 & $3.22 \%$ \\
\hline \multirow{2}{*}{$\mathrm{O}_{21}$} & N - 45.1029, E - 23.7979, max.r.l. - 9.5 m, min.r.l. & S.c. & 2 & $20 \%$ \\
& -5 m, max.w.d. - 74 cm S. 16 (Alimpești) & P.p. & 8 & $80 \%$ \\
\hline \multirow{2}{*}{$\mathrm{O}_{22}$} & N - 45.0836, E - 23.8006, max.r.l. - 11 m, min.r.l. & S.c. & 4 & $44.44 \%$ \\
& -5 m, max.w.d. - 63 cm S. 17 (Alimpești II) & A.b. & 5 & $55.55 \%$ \\
\hline \multirow{3}{*}{$\mathrm{O}_{23}$} & N - 45.0703, E - 23.8043, max.r.l. - 10 m, min.r.l. & S.c. & 1 & $4.16 \%$ \\
& -7 m, max.w.d. - 60 cm S. 18 (Nistorești) & A.b. & 20 & $83.33 \%$ \\
& & B.m. & 2 & $8.33 \%$ \\
& & O.b. & 1 & $4.16 \%$ \\
\hline
\end{tabular}


In $\mathrm{O}_{18}$ the significant upstream human impact are still visible in the low number of species and individuals, in contradiction with the passing of the river in a new geographical unit category (Mateeşti and Sârbeşti hills area) which should induce an increase in fish species number. In $\mathrm{O}_{19}$ the second station of this sector, the river quality is recovering and the upper Mediterranean barbel species are still present and dominant. Downstream, the Common nase zone characteristic fish associations structure reveal a medium human impact on the natural habitats (Fig. 16), due to lotic habitat's fragmentation (Figs. 17-19), industrial (coal exploitation) pollution and riverine localities waste waters pollution (Tabs. 3a, b). CFIBI score vary between 30 and 24, reflecting some expected species to be absent or rare, omnivores and tolerant species as dominant. The passing of the river in the next hills area (Cerna and Amaradia hills) induce/increase/double the fish species number (Tab. 3b).

Table 3b: The sampled fish, in Common nase zone $\left(\mathrm{O}_{24}-\mathrm{O}_{32}\right)$; Barbus meridionalis - B.m.; Alburnoides bipunctatus - A.b.; Squalius cephalus - S.c.; Orthrias barbatulus - O.b.; Gobio uranoscopus - G.u.; Gobio gobio - G.g.; Sabanejewia romanica - S.r.

\begin{tabular}{|c|c|c|c|c|}
\hline $\mathrm{O}_{24}$ & $\begin{array}{l}\text { N - 45.0489, E - 23.8053, max.r.l. - } 11 \text { m, min.r.l. } \\
\text { - } 8 \text { m, max.w.d. - } 1 \text { m.S. } 19 \text { (Alun Dam) }\end{array}$ & $\begin{array}{l}\text { S.c. } \\
\text { A.b. } \\
\text { B.m. }\end{array}$ & $\begin{array}{l}1 \\
7 \\
5\end{array}$ & $\begin{array}{l}7.69 \% \\
53.84 \% \\
38.46 \% \\
\end{array}$ \\
\hline $\mathrm{O}_{25}$ & $\begin{array}{l}\text { N - 45.0359, E - 23.8158, max.r.l. - } 14 \text { m, min.r.l. } \\
\text { - } 7 \text { m, max.w.d. - } 60 \mathrm{~cm} \text { S. } 20 \text { (Alun) }\end{array}$ & $\begin{array}{l}\text { S.c. } \\
\text { A.b. }\end{array}$ & $\begin{array}{l}1 \\
9\end{array}$ & $\begin{array}{l}10 \% \\
90 \%\end{array}$ \\
\hline $\mathrm{O}_{26}$ & $\begin{array}{l}\mathrm{N}-45.0049, \mathrm{E}-23.8227, \text { max.r.l. - } 12.5 \mathrm{~m} \text {, } \\
\text { min.r.l. - } 7 \mathrm{~m} \text {, max.w.d. - } 54 \mathrm{~cm} \mathrm{S.} 21 \text { (Alun coal } \\
\text { exploitation) }\end{array}$ & $\begin{array}{l}\text { S.c. } \\
\text { A.b. } \\
\text { G.u. } \\
\text { B.m. }\end{array}$ & $\begin{array}{c}5 \\
20 \\
1 \\
7\end{array}$ & $\begin{array}{c}15.15 \% \\
60.60 \% \\
3.03 \% \\
21.21 \%\end{array}$ \\
\hline $\mathrm{O}_{27}$ & $\begin{array}{l}\text { N - 44.9823, E - 23.8247, max.r.l. - } 10 \text { m, min.r.l. } \\
\text { - } 4 \text { m, max.w.d. - } 90 \text { cm S. } 22 \text { (Alun IV) }\end{array}$ & $\begin{array}{l}\text { A.b. } \\
\text { G.u. } \\
\text { B.m. }\end{array}$ & $\begin{array}{c}24 \\
2 \\
7 \\
\end{array}$ & $\begin{array}{c}72.72 \% \\
6.06 \% \\
21.21 \% \\
\end{array}$ \\
\hline $\mathrm{O}_{28}$ & $\begin{array}{l}\text { N - 44.9723, E - 23.8205, max.r.l. - } 7.8 \text { m, min.r.l. } \\
\text { - } 7.3 \text { m, max.w.d. - } 1 \text { m S. } 23 \text { (Colţești) }\end{array}$ & $\begin{array}{l}\text { A.b. } \\
\text { G.g. } \\
\text { G.u. } \\
\text { B.m. } \\
\text { S.r. }\end{array}$ & $\begin{array}{c}1 \\
1 \\
6 \\
10 \\
12 \\
\end{array}$ & $\begin{array}{c}3.33 \% \\
3.33 \% \\
20 \% \\
33.33 \% \\
36.36 \% \\
\end{array}$ \\
\hline $\mathrm{O}_{29}$ & $\begin{array}{l}\text { N - 44.9432, E - 23.8349, max.r.l. - } 10 \text { m, min.r.l. } \\
\text { - } 3 \text { m, max.w.d. - } 40 \text { cm S. } 24 \text { (Between Popești } \\
\text { and Sinești) }\end{array}$ & $\begin{array}{l}\text { S.c. } \\
\text { A.b. } \\
\text { G.u. } \\
\text { B.m. } \\
\text { O.b. } \\
\text { S.r. }\end{array}$ & $\begin{array}{c}56 \\
11 \\
5 \\
13 \\
2 \\
28 \\
\end{array}$ & $\begin{array}{c}48.69 \% \\
9.56 \% \\
4.34 \% \\
11.30 \% \\
1.73 \% \\
24.34 \%\end{array}$ \\
\hline $\mathrm{O}_{30}$ & $\begin{array}{l}\text { N - 44.9151, E - 23.8293, max.r.l. - } 9 \text { m, min.r.l. - } \\
5 \text { m, max.w.d. - } 42 \text { cm S. } 25 \text { (Urzica) }\end{array}$ & $\begin{array}{c}\mathrm{Sc} \\
\mathrm{Ab} \\
\mathrm{Gu} \\
\mathrm{Bm} \\
\mathrm{Sr}\end{array}$ & $\begin{array}{c}21 \\
8 \\
2 \\
4 \\
38\end{array}$ & $\begin{array}{l}28.76 \% \\
10.95 \% \\
2.73 \% \\
5.47 \% \\
52.05 \%\end{array}$ \\
\hline $\mathrm{O}_{31}$ & $\begin{array}{l}\text { N - 44.8811, E - 23.8327, max.r.l. - } 15 \text { m, min.r.l. } \\
\text { - } 6 \text { m, max.w.d. - } 1.5 \text { m S. } 26 \text { (Grădiștea) }\end{array}$ & $\begin{array}{c}\mathrm{Sc} \\
\mathrm{Ab} \\
\mathrm{Gu} \\
\mathrm{Bm} \\
\mathrm{Sr}\end{array}$ & $\begin{array}{c}14 \\
3 \\
31 \\
4 \\
12\end{array}$ & $\begin{array}{c}21.87 \% \\
4.68 \% \\
48.43 \% \\
6.25 \% \\
18.75 \%\end{array}$ \\
\hline $\mathrm{O}_{32}$ & $\begin{array}{l}\text { N - 44.8485, E - 23.8359, max.r.l. - } 13 \text { m, min.r.l. } \\
\text { - } 6 \text { m max.w.d. - } 77 \text { cm S. } 27 \text { (Tina) }\end{array}$ & $\begin{array}{c}\mathrm{Sc} \\
\mathrm{Ab} \\
\mathrm{Gu} \\
\mathrm{Bm} \\
\mathrm{Sr}\end{array}$ & $\begin{array}{c}34 \\
21 \\
34 \\
2 \\
4 \\
\end{array}$ & $\begin{array}{c}35.78 \% \\
22.10 \% \\
35.78 \% \\
2.10 \% \\
4.21 \% \\
\end{array}$ \\
\hline
\end{tabular}




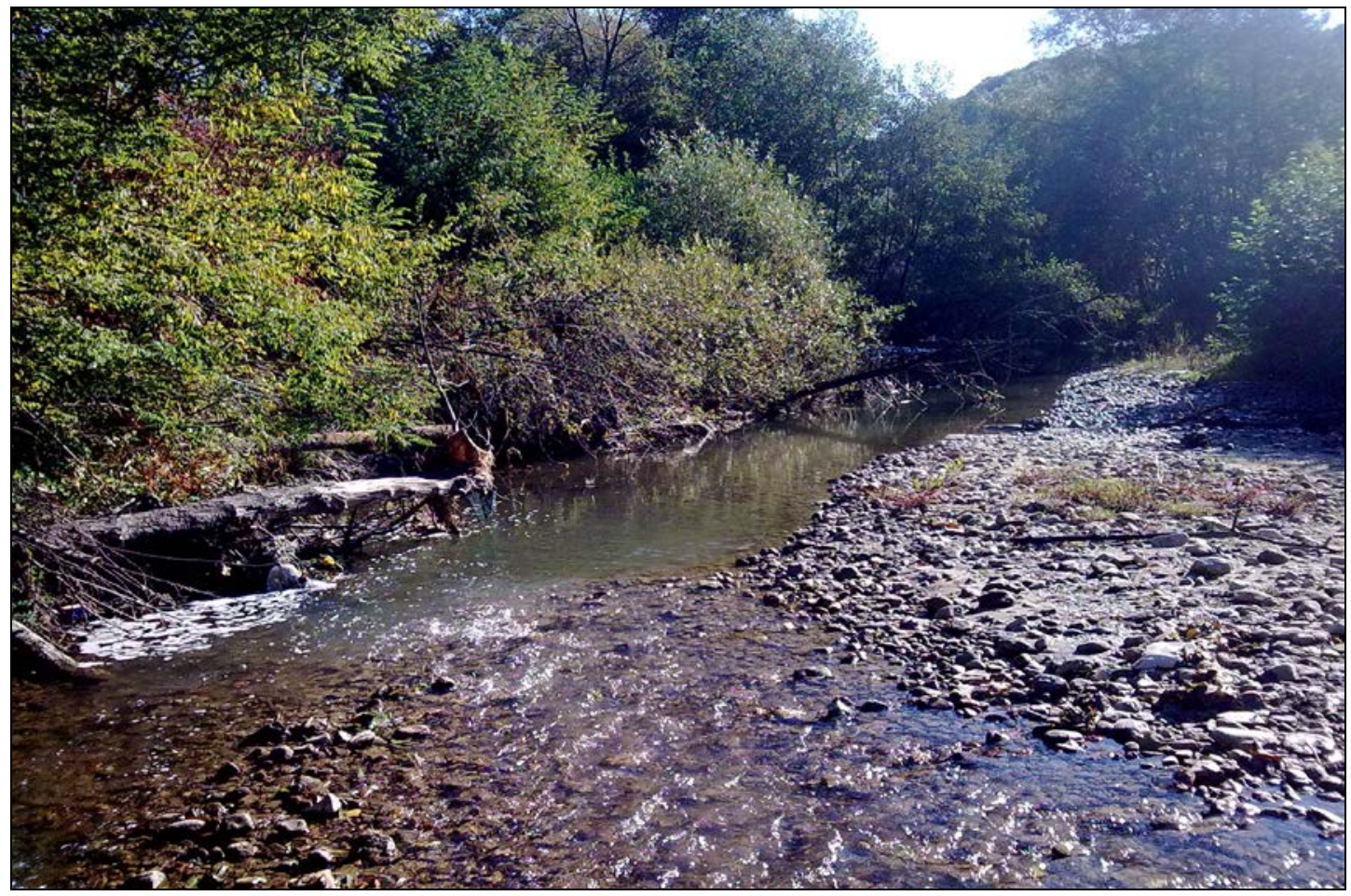

Figure 16: Natural habitat of the river in the Common nase area.

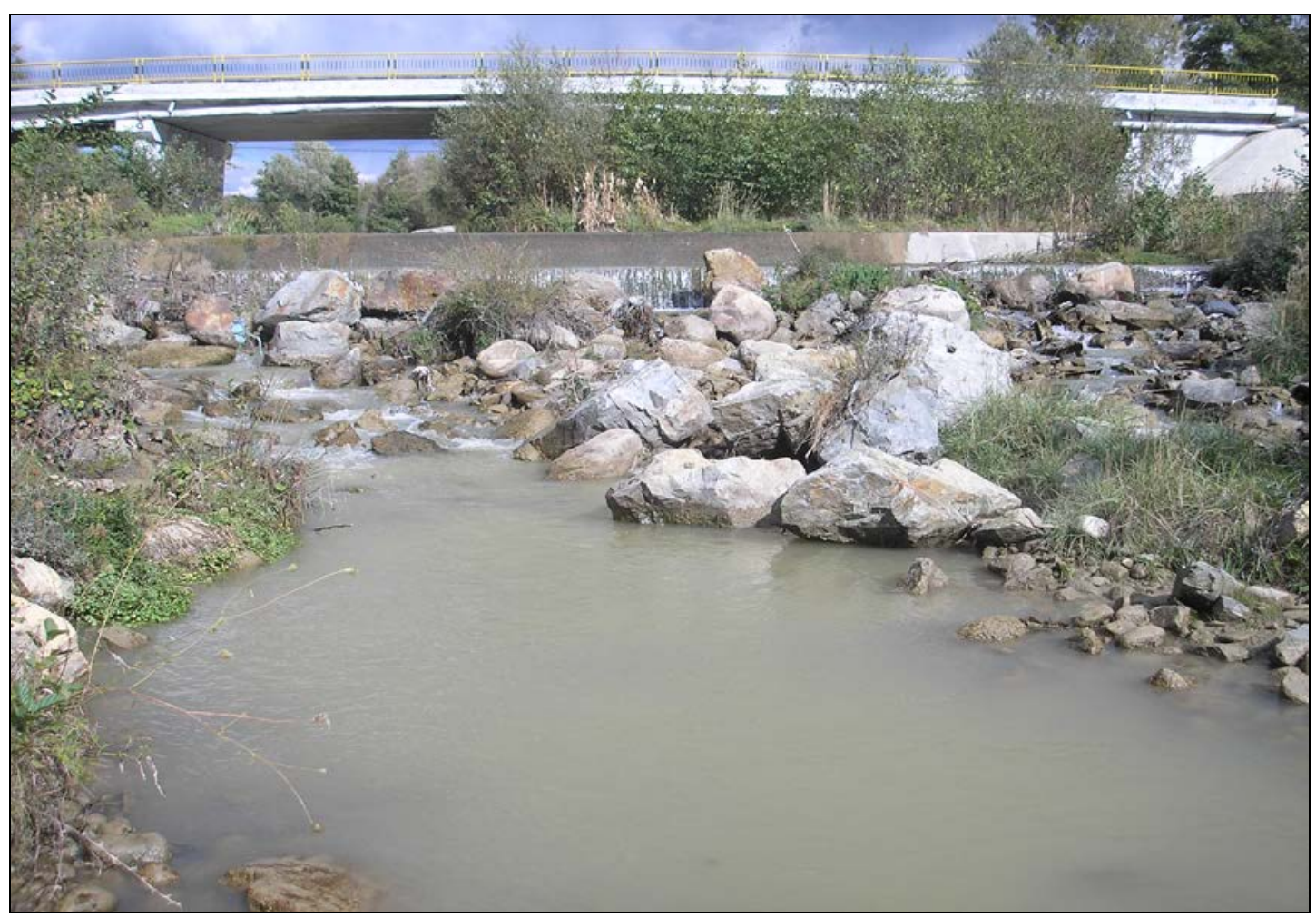

Figure 17: Stone steps which do not permit the fish to migrate. 


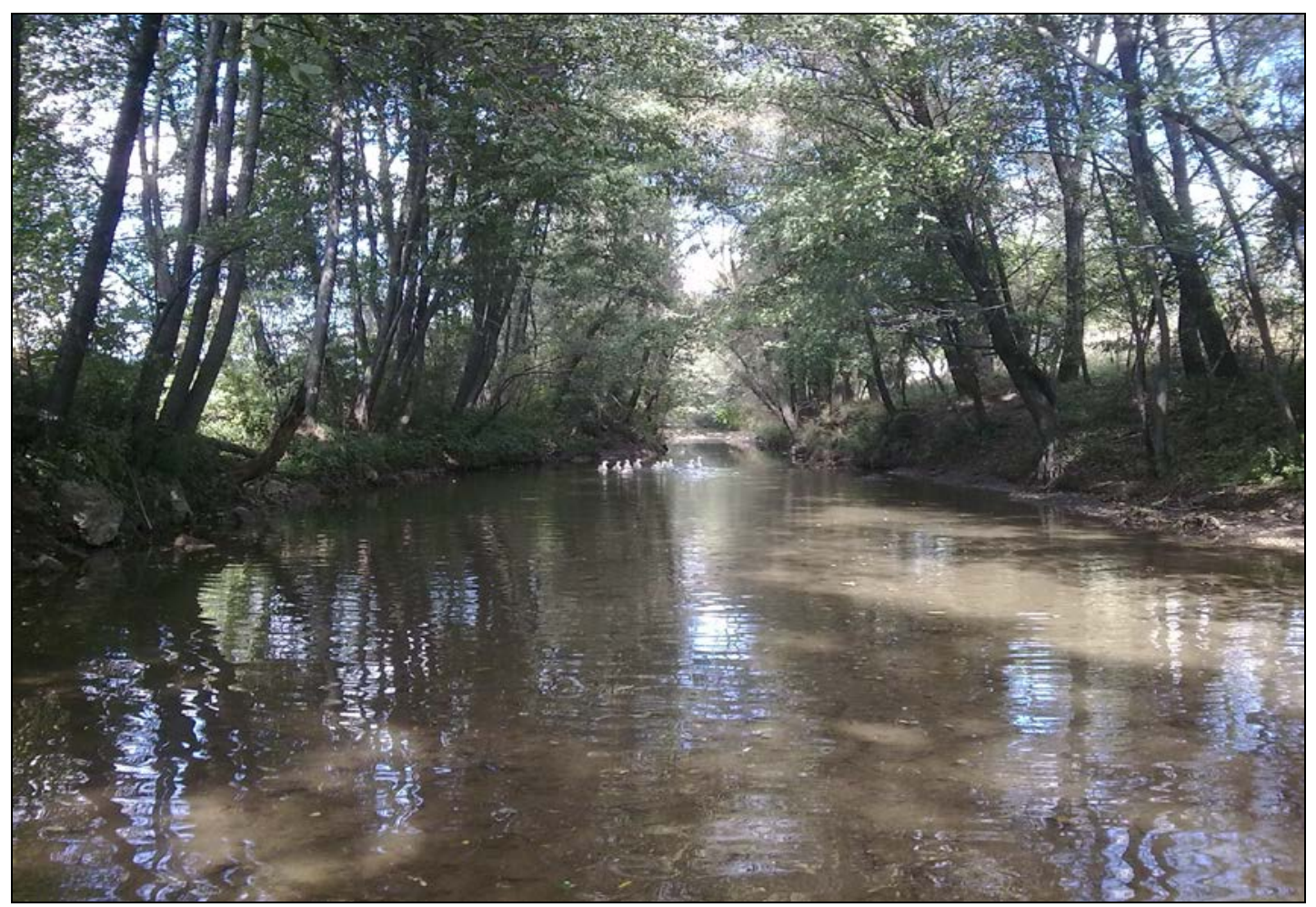

Figure 18: Unnatural lentic habitat and sand accumulation due to a downstream dam.

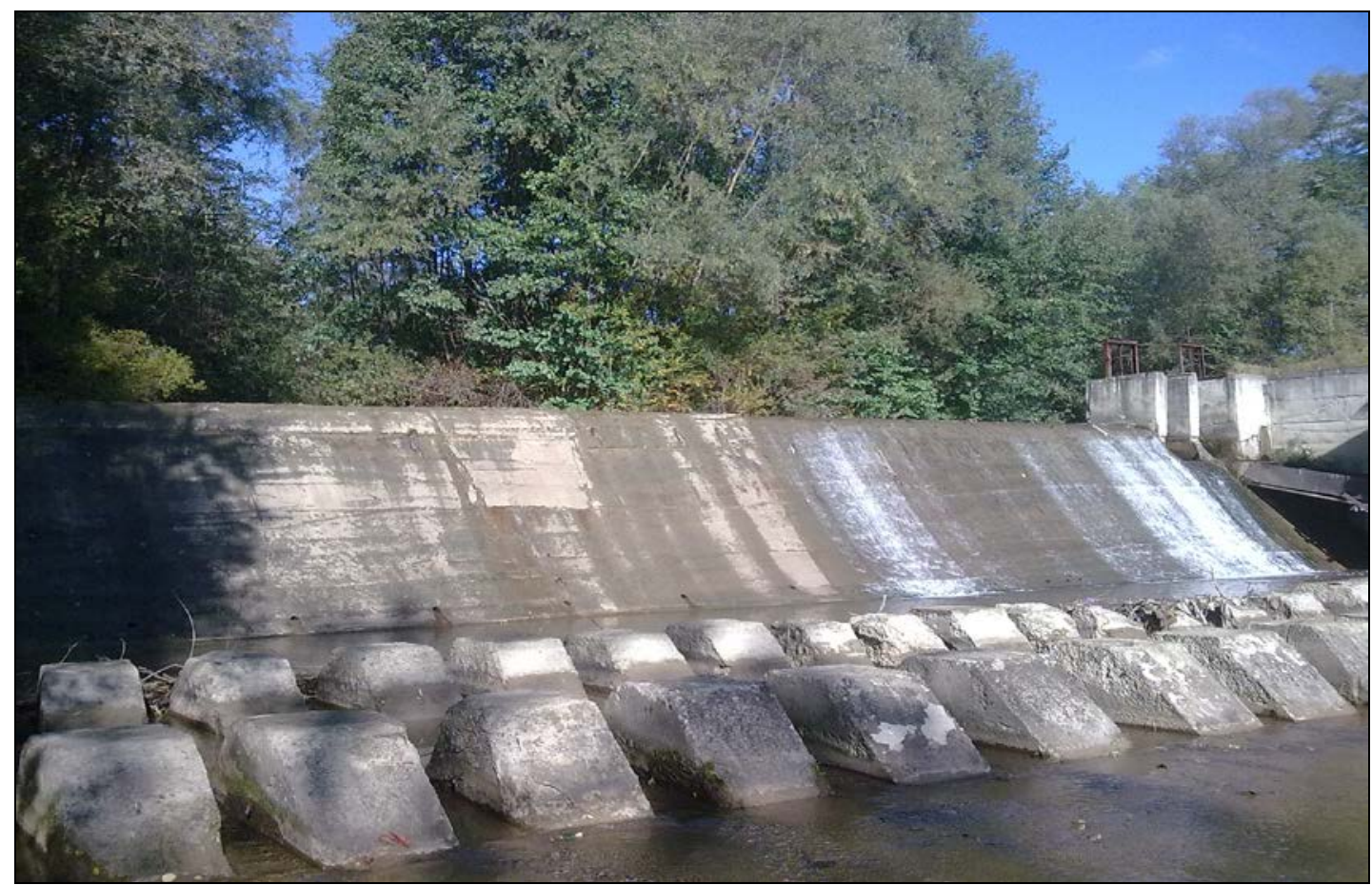

Figure 19: Dam which creates upstream unnatural lentic sectors. 
4 Downstream, the river flows from the hills area (Amaradia and Cerna hills) to the plateau area (Beicăi and Teslui plateaus) passing the Podişul Getic - southern sector, and in this sector the ichthyofauna structure is shifting to the Barbel zone (Tab. 4a, b), in conformity with the Bănărescu ichthyological zonation (1964). CF-IBI score vary between 32 and 25, reflecting a decrease in the abundance of sensitive species, some expected species absent or rare, omnivores and tolerant species as dominant.

Table 4a: The sampled fish material, in the upper barbell zone area of Olteţ River $\left(\mathrm{O}_{33}-\mathrm{O}_{40}\right)$; Squalius cephalus - S.c.; Barbus meridionalis - B.m.; Alburnoides bipunctatus A.b.; Gobio gobio - G.g.; Gobio uranoscopus - G.u.; Barbus barbus - B.b.; Sabanejewia romanica - S.r.; Alburnus alburnus - A.a.

\begin{tabular}{|c|c|c|c|c|}
\hline $\mathrm{O}_{33}$ & $\begin{array}{l}\mathrm{N}-44.8182, \\
\text { E - 23.8326, } \\
\text { max.r.l. - } 17 \mathrm{~m} \text {, min.r.l. - } 12 \mathrm{~m} \text {, } \\
\text { max.w.d. }-53 \mathrm{~cm}\end{array}$ & $\begin{array}{c}S c \\
A b \\
G g \\
G u \\
B b \\
B m \\
S r\end{array}$ & $\begin{array}{c}5 \\
4 \\
1 \\
22 \\
1 \\
5 \\
1\end{array}$ & $\begin{array}{c}12.82 \% \\
10.25 \% \\
2.56 \% \\
56.41 \% \\
2.56 \% \\
12.82 \% \\
2.56 \%\end{array}$ \\
\hline $\mathrm{O}_{34}$ & $\begin{array}{l}\mathrm{N}-44.7897, \\
\mathrm{E}-23.8417, \\
\text { max.r.l. - } 17.3 \mathrm{~m} \text {, min.r.l. - } 12 \mathrm{~m} \text {, } \\
\text { max.w.d. - } 40 \mathrm{~cm}\end{array}$ & $\begin{array}{c}S c \\
A a \\
A b \\
G g \\
G u \\
B m \\
S r\end{array}$ & $\begin{array}{c}12 \\
1 \\
9 \\
1 \\
9 \\
1 \\
2\end{array}$ & $\begin{array}{c}34.28 \% \\
2.85 \% \\
25.71 \% \\
2.85 \% \\
25.71 \% \\
2.85 \% \\
5.71 \%\end{array}$ \\
\hline $\mathrm{O}_{35}$ & $\begin{array}{l}\mathrm{N}-44.7794, \\
\mathrm{E}-23.8578, \\
\text { max.r.l. - } 31.8 \mathrm{~m} \text {, min.r.l. - } 19.1 \mathrm{~m} \text {, } \\
\text { max.w.d. - } 54 \mathrm{~cm}\end{array}$ & $\begin{array}{c}S c \\
A b \\
G u \\
B m \\
S r\end{array}$ & $\begin{array}{c}15 \\
10 \\
13 \\
1 \\
1\end{array}$ & $\begin{array}{c}37.5 \% \\
25 \% \\
32.5 \% \\
2.5 \% \\
2.5 \%\end{array}$ \\
\hline $\mathrm{O}_{36}$ & $\begin{array}{l}\mathrm{N}-44.7140, \\
\mathrm{E}-23.9067, \\
\text { max.r.l. - } 45.8 \mathrm{~m} \text {, min.r.l. - } 28.8 \mathrm{~m} \text {, } \\
\text { max.w.d. - } 75.2 \mathrm{~cm} \text { S. }\end{array}$ & $\begin{array}{l}S c \\
A a \\
A b \\
G u \\
B m \\
\end{array}$ & $\begin{array}{c}32 \\
8 \\
5 \\
15 \\
2 \\
\end{array}$ & $\begin{array}{c}51.61 \% \\
12.90 \% \\
8.06 \% \\
24.19 \% \\
3.22 \% \\
\end{array}$ \\
\hline $\mathrm{O}_{37}$ & $\begin{array}{l}\mathrm{N}-44.6661, \\
\mathrm{E}-23.9254, \\
\text { max.r.l. - } 43 \mathrm{~m} \text {, min.r.l. - } 32.5 \mathrm{~m} \text {, } \\
\text { max.w.d. - } 30 \mathrm{~cm}\end{array}$ & $\begin{array}{c}S c \\
A a \\
A b \\
G u \\
B m \\
S r\end{array}$ & $\begin{array}{c}68 \\
1 \\
55 \\
15 \\
5 \\
4\end{array}$ & $\begin{array}{c}45.94 \% \\
0.67 \% \\
37.16 \% \\
10.13 \% \\
3.37 \% \\
2.70 \%\end{array}$ \\
\hline $\mathrm{O}_{38}$ & $\begin{array}{l}\mathrm{N}-44.6364, \\
\mathrm{E}-23.9560 \text {, } \\
\text { max.r.l. - } 37 \mathrm{~m} \text {, min.r.l. - } 24 \mathrm{~m} \text {, } \\
\text { max.w.d. }-44 \mathrm{~cm}\end{array}$ & $\begin{array}{c}S c \\
A b \\
G g \\
G u \\
B m \\
S r\end{array}$ & $\begin{array}{c}32 \\
6 \\
1 \\
1 \\
1 \\
1 \\
\end{array}$ & $\begin{array}{c}76.19 \% \\
14.28 \% \\
2.38 \% \\
2.38 \% \\
2.38 \% \\
2.38 \% \\
\end{array}$ \\
\hline
\end{tabular}


Table 4a (continuing): The sampled fish material, in the upper barbell zone area of Olteţ River $\left(\mathrm{O}_{39}-\mathrm{O}_{40}\right)$; Squalius cephalus - S.c.; Alburnoides bipunctatus - A.b.; Gobio gobio - G.g.; Gobio uranoscopus - G.u.; Sabanejewia romanica - S.r.; Alburnus alburnus A.a.

\begin{tabular}{|c|l|c|c|c|}
\hline & N - 44.6120, & $S c$ & 44 & $83.01 \%$ \\
$\mathrm{O}_{39}$ & E - 23.9606, & $G g$ & 1 & $1.88 \%$ \\
& max.r.l. - 53.4 m, min.r.l. - 46 m, & $\mathrm{Bm}$ & 4 & $7.54 \%$ \\
& max.w.d. - 64 cm & $\mathrm{Sr}$ & 4 & $7.54 \%$ \\
\hline \multirow{3}{*}{$\mathrm{O}_{40}$} & N - 44.5653, & $S c$ & 33 & $73.33 \%$ \\
& E - 23.9800, & $\mathrm{Aa}$ & 1 & $2.22 \%$ \\
& max.r.l. - 88.7 m, min.r.l. - 64 m, & $\mathrm{Ab}$ & 4 & $8.88 \%$ \\
& max.w.d. - 50 cm & $\mathrm{Gu}$ & 1 & $2.22 \%$ \\
& & $\mathrm{Bm}$ & 4 & $8.88 \%$ \\
& & $\mathrm{Sr}$ & 2 & $4.44 \%$ \\
\hline
\end{tabular}

Table 4b: The sampled fish material, in the lower barbell zone area of Olteţ River $\left(\mathrm{O}_{41}-\mathrm{O}_{43}\right)$; Squalius cephalus - S.c.; Alburnoides bipunctatus - A.b.; Rhodeus sericeus amarus - R.s.a.; Carasius auratus gibelio - C.a.g.; Barbus barbus - B.b.; Sabanejewia romanica - S.r.; Sabanejewia aurata - S.a.; Pseudorasbora parva - P.pa.; Alburnus alburnus - A.a.; Romanogobio kessleri - R.k.

\begin{tabular}{|c|l|c|c|c|}
\hline \multirow{3}{*}{$\mathrm{O}_{41}$} & $\mathrm{~N}-$ 44.5338, & $A b$ & 7 & $58.33 \%$ \\
& E - 23.9996, & $R s a$ & 2 & $12.66 \%$ \\
& max.r.l. - 61 m, min.r.l., max.w.d. - & $P p$ & 1 & $8.33 \%$ \\
& $61 \mathrm{~cm}$ & $\mathrm{Cag}$ & 2 & $12.66 \%$ \\
\hline \multirow{6}{*}{$\mathrm{O}_{42}$} & $\mathrm{~N}-44.5158$, & $S c$ & 73 & $35.96 \%$ \\
& E - 24.0252, & $A a$ & 1 & $0.49 \%$ \\
& max.r.l. - 55 m, min.r.l., max.w.d. - & $R s a$ & 12 & $5.91 \%$ \\
& $40 \mathrm{~cm}$ & $R k$ & 20 & $9.85 \%$ \\
& & $B b$ & 14 & $6.89 \%$ \\
& & $S r$ & 3 & $1.47 \%$ \\
& & $S a$ & 80 & $39.40 \%$ \\
\hline \multirow{5}{*}{$\mathrm{O}_{43}$} & $\mathrm{~N}-44.4845$, & $S c$ & 105 & $52.23 \%$ \\
& E - 24.0806, & $A a$ & 1 & $0.49 \%$ \\
& max.r.l. - 60 m, min.r.l. - 28 m, & $R s a$ & 1 & $0.49 \%$ \\
& max.w.d. - 50 cm & $R k$ & 25 & $12.43 \%$ \\
& & $B b$ & 6 & $2.98 \%$ \\
& & $S a$ & 63 & $31.34 \%$ \\
\hline
\end{tabular}


Table $4 \mathrm{~b}$ (continuing): The sampled fish material, in the lower barbell zone area of Olteţ River $\left(\mathrm{O}_{44}-\mathrm{O}_{47}\right)$; Squalius cephalus - S.c.; Rhodeus sericeus amarus - R.s.a.; Carasius auratus gibelio - C.a.g.; Gobio gobio - G.g.; Barbus b - B.b.; Sabanejewia romanica - S.r.; Sabanejewia aurata - S.a.; Pseudorasbora parva - P.pa.; Romanogobio kessleri - R.k.

\begin{tabular}{|c|l|c|c|c|}
\hline \multirow{5}{*}{$\mathrm{O}_{44}$} & N - 44.4611, & $S c$ & 235 & $74.73 \%$ \\
& E - 24.0951, & $R s a$ & 3 & $0.82 \%$ \\
& max.r.l. - 40 m, min.r.l. - 21 m, & $R k$ & 25 & $6.88 \%$ \\
& max.w.d. - 40 cm & $B b$ & 16 & $4.40 \%$ \\
& & $S r$ & 1 & $0.27 \%$ \\
& & $S a$ & 83 & $22.86 \%$ \\
\hline \multirow{5}{*}{$\mathrm{O}_{45}$} & N - 44.4487, & $S c$ & 180 & $64.05 \%$ \\
& E - 24.1105, & $R s a$ & 8 & $2.84 \%$ \\
& max.r.l. - 46 m; min.r.l. - 25 m, & $G g$ & 5 & $1.77 \%$ \\
& max.w.d. - 60 cm & $R k$ & 13 & $4.62 \%$ \\
& & $B b$ & 6 & $2.13 \%$ \\
& & $C a g$ & 1 & $0.35 \%$ \\
& & $S r$ & 2 & $0.71 \%$ \\
& & $S a$ & 66 & $23.48 \%$ \\
\hline \multirow{5}{*}{$\mathrm{O}_{46}$} & N - 44.4208, & $S c$ & 263 & $78.74 \%$ \\
& E - 24.1069, & $R s a$ & 6 & $1.79 \%$ \\
& max.r.l. - 60 cm, min.r.l. - 20 m, & $G g$ & 2 & $0.59 \%$ \\
& max.w.d. - 56 cm & $R k$ & 10 & $2.99 \%$ \\
& & $B b$ & 15 & $4.49 \%$ \\
& & $S a$ & 38 & $11.37 \%$ \\
\hline \multirow{5}{*}{$\mathrm{O}_{47}$} & N - 44.3936, & $S c$ & 146 & $50 \%$ \\
& E - 24.1121, & $R s a$ & 16 & $5.47 \%$ \\
& max.r.l. - 46 m, min.r.l. - 32 m, & $G g$ & 5 & $1.71 \%$ \\
& max.w.d. - 60 cm & $R k$ & 3 & $1.02 \%$ \\
& & $P p a$ & 1 & $0.34 \%$ \\
& & $B b$ & 2 & $0.68 \%$ \\
& & $C a g$ & 1 & $0.34 \%$ \\
& & $S a$ & 118 & $40.41 \%$ \\
\hline
\end{tabular}

The river passing from hills area to plateau area, the significant increasing of the Olteţ River water volume due to some important tributaries (Fig. 20) and the dominance of fine sand river bed sectors (Fig. 21) is the natural explanation for the local ichthyofauna shifting to the Barbel zone.

The deviations of the ichthyofauna structure from the natural Barbel zone one in the Romanian Carpathians (Bănărescu, 1964) in these sectors can be explained by the local human impacts like: pollution, habitat modifications (Fig. 23), roads in the riverbed and illegal fishing (Fig. 22). 


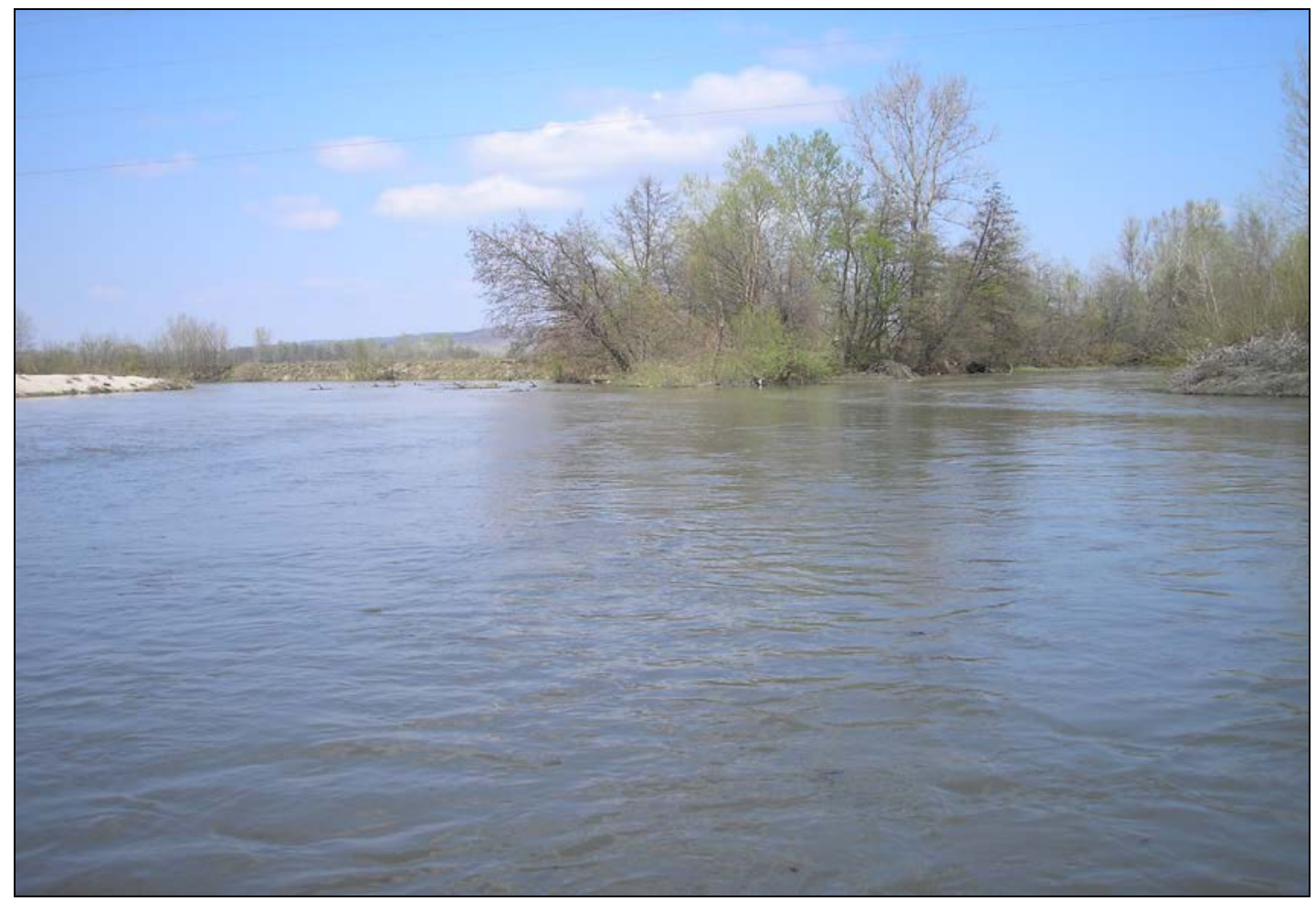

Figure 20: Confluence of Olteţ River with Cerna River (Olteţ River biggest tributary).

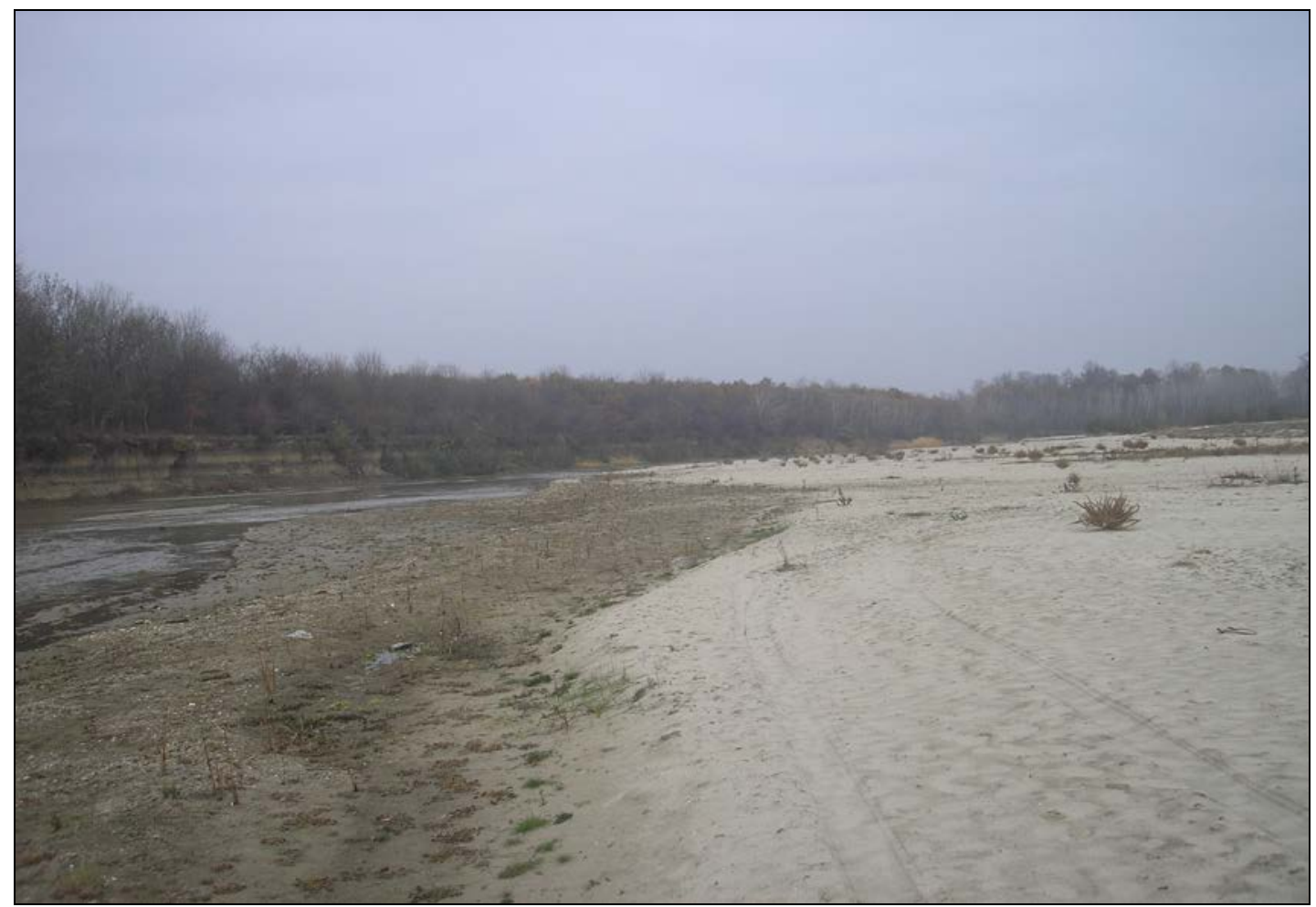

Figure 21: The appearance of massive fine sandy riverbeds and banks areas. 


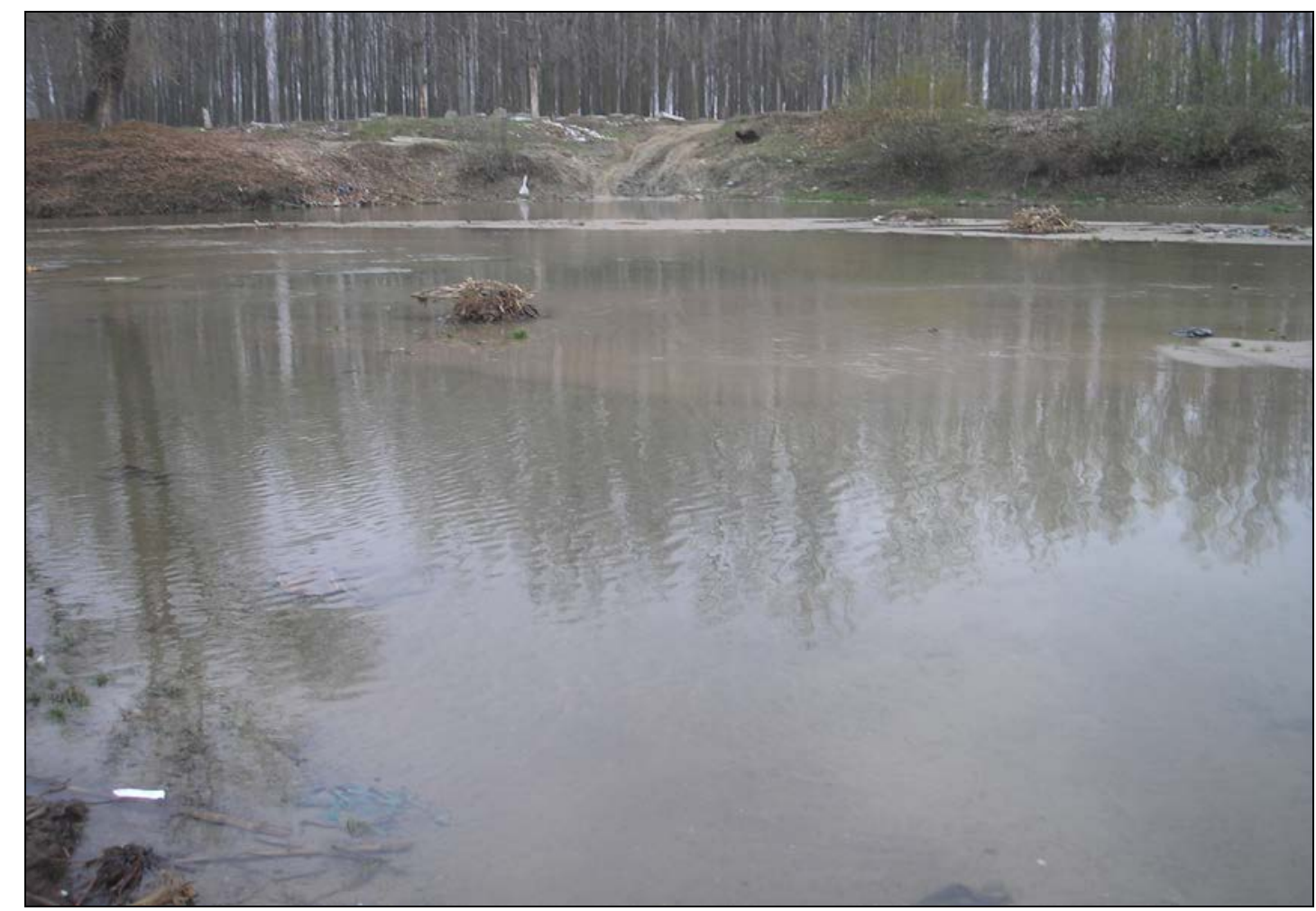

Figure 22: Roads in the river.

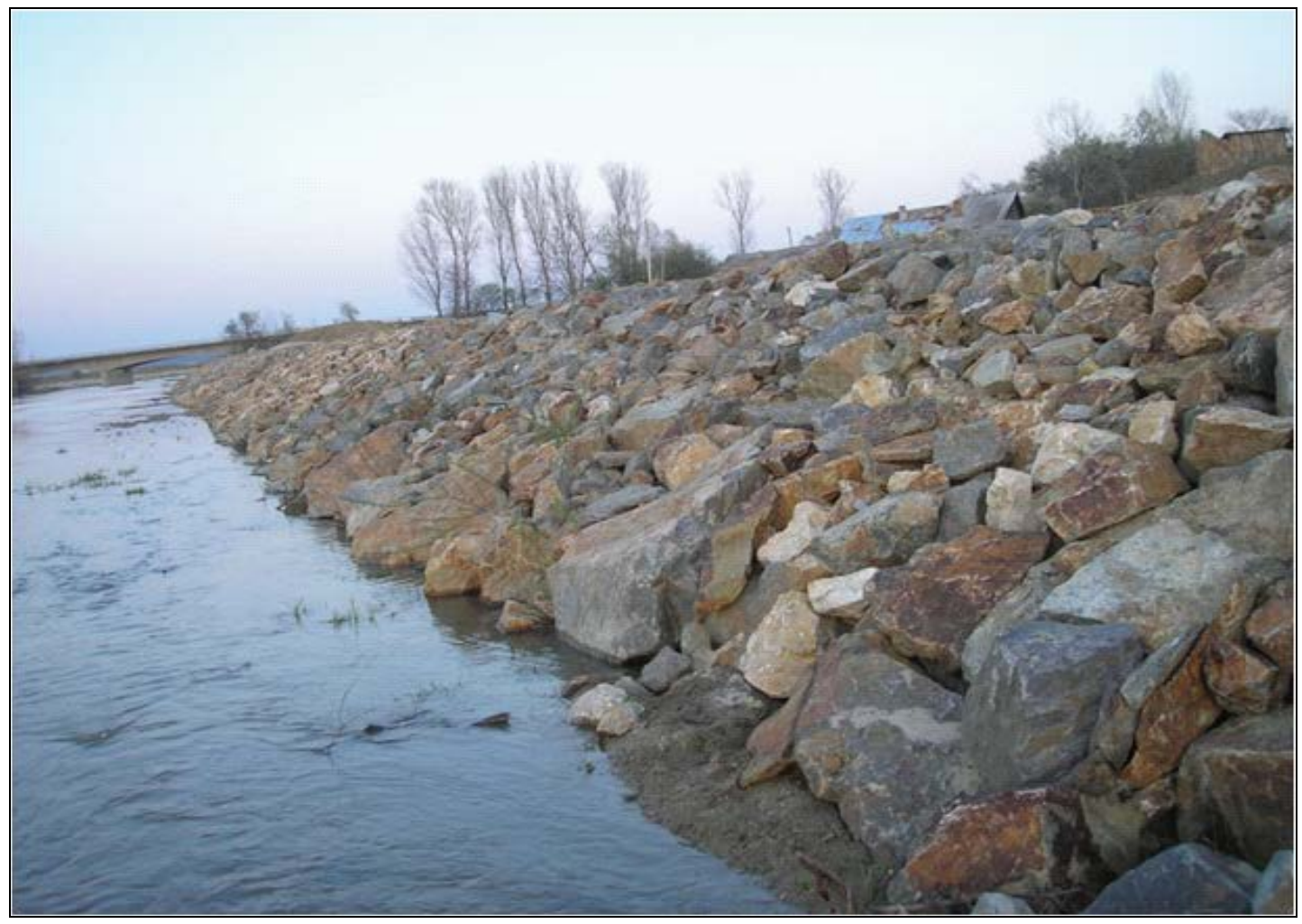

Figure 23: River linearization using rockfill banks; near the Dinculeşti locality. 
(5 Downstream the river flows in and passes (48-55 sampling stations) the Câmpia Română/Romanian Plain sector, (Caracal Plain and Olt River meadow) sector which has an ichthyofauna structure that is shifting to the Carp zone, in conformity with the Bănărescu ichthyological zonation (1964).

Table 5: The sampled fish material, in the Carp zone area of Olteţ River $\left(\mathrm{O}_{48}-\mathrm{O}_{56}\right)$; Squalius cephalus - S.c.; Rhodeus sericeus amarus - R.s.a.; Gobio gobio - G.g.; Romanogobio kesleri - R.k.; Barbus meridionalis - B.m.; Barbus barbus - B.b.; Carasius auratus gibelio - C.a.g.; Sabanejewia romanica - S.r.; Sabanejewia aurata - S.a.; Lepomis gibosus - L.g.; Alburnus alburnus - A.a.; Perca fluviatilis - P.f.; Pelecus cultratus - P.c.; Silurus glanis - S.g.; 48-55 - quantitative samplings, 56 - qualitative samplings.

\begin{tabular}{|c|c|c|c|c|}
\hline $\mathrm{O}_{48}$ & $\begin{array}{l}\mathrm{N}-44.3715, \\
\mathrm{E}-24.1108, \\
\text { max.r.l. - } 55 \mathrm{~m} \text {, min.r.l. - } 35 \mathrm{~m} \text {, } \\
\text { max.w.d. - } 35 \mathrm{~cm} .\end{array}$ & $\begin{array}{c}S c \\
R s a \\
G g \\
R k \\
B m \\
C a g \\
S r \\
S a \\
L g\end{array}$ & $\begin{array}{c}63 \\
9 \\
15 \\
8 \\
1 \\
1 \\
1 \\
8 \\
2\end{array}$ & $\begin{array}{c}56.25 \% \\
8.03 \% \\
13.39 \% \\
7.14 \% \\
0.89 \% \\
0.89 \% \\
0.89 \% \\
7.14 \% \\
1.78 \%\end{array}$ \\
\hline $\mathrm{O}_{49}$ & $\begin{array}{l}\mathrm{N}-44.3448, \\
\text { E - 24.1015, } \\
\text { max.r.l. - } 39 \mathrm{~m} \text {, min.r.l. - } 22 \mathrm{~m} \text {, } \\
\text { max.w.d. }-50 \mathrm{~cm}\end{array}$ & $\begin{array}{c}S c \\
R s a \\
G g \\
R k \\
B m \\
C a g \\
S a\end{array}$ & $\begin{array}{c}62 \\
2 \\
3 \\
12 \\
1 \\
2 \\
42\end{array}$ & $\begin{array}{c}50 \% \\
1.61 \% \\
2.41 \% \\
9.67 \% \\
0.80 \% \\
1.61 \% \\
33.87 \%\end{array}$ \\
\hline $\mathrm{O}_{50}$ & $\begin{array}{l}\mathrm{N}-44.3207, \\
\text { E - 24.1217, } \\
\text { max.r.l. - } 60 \mathrm{~m} \text {, min.r.l. - } 39 \mathrm{~m} \text {, } \\
\text { max.w.d. - } 55 \mathrm{~cm} .\end{array}$ & $\begin{array}{c}S c \\
R s a \\
G g \\
R k \\
C a g \\
S r \\
S a\end{array}$ & $\begin{array}{c}5 \\
3 \\
2 \\
77 \\
1 \\
1 \\
44\end{array}$ & $\begin{array}{c}3.75 \% \\
2.25 \% \\
1.50 \% \\
57.89 \% \\
0.75 \% \\
0.75 \% \\
33.08 \% \\
\end{array}$ \\
\hline $\mathrm{O}_{51}$ & $\begin{array}{l}\mathrm{N}-44.2855, \\
\text { E - 24.2213, } \\
\text { max.r.l. - } 72 \mathrm{~m} \text {, min.r.l. - } 35 \mathrm{~m} \text {, } \\
\text { max.w.d. - } 55 \mathrm{~cm} .\end{array}$ & $\begin{array}{c}S c \\
A a \\
R s a \\
G g \\
R k \\
B b \\
B m \\
C a g \\
S r \\
S a\end{array}$ & $\begin{array}{c}48 \\
1 \\
2 \\
2 \\
18 \\
1 \\
1 \\
7 \\
1 \\
70\end{array}$ & $\begin{array}{c}31.78 \% \\
0.66 \% \\
1.32 \% \\
1.32 \% \\
11.92 \% \\
0.66 \% \\
0.66 \% \\
4.63 \% \\
0.66 \% \\
46.35 \%\end{array}$ \\
\hline
\end{tabular}




\begin{tabular}{|c|c|c|c|c|}
\hline $\mathrm{O}_{52}$ & $\begin{array}{l}\mathrm{N}-44.2844, \\
\mathrm{E}-24.2446, \\
\text { max.r.l. - } 66 \mathrm{~m} \text {, min.r.l. - } 25 \mathrm{~m} \text {, } \\
\text { max.w.d. }-60 \mathrm{~cm}\end{array}$ & $\begin{array}{c}S c \\
R s a \\
R k \\
C a g \\
\text { Sa } \\
\end{array}$ & $\begin{array}{c}7 \\
1 \\
51 \\
1 \\
235 \\
\end{array}$ & $\begin{array}{c}2.37 \% \\
0.33 \% \\
17.28 \% \\
0.33 \% \\
79.66 \% \\
\end{array}$ \\
\hline $\mathrm{O}_{53}$ & $\begin{array}{l}\mathrm{N}-44.2331, \mathrm{E}-24.3396 \text {, max.r.l. - } \\
50 \text { m, min.r.l. - } 20 \text { m, max.w.d. - } 70 \\
\text { cm }\end{array}$ & $\begin{array}{c}S c \\
\mathrm{Aa} \\
\mathrm{Gg} \\
R k \\
\mathrm{Bm} \\
\mathrm{Cag} \\
\mathrm{Sa}\end{array}$ & $\begin{array}{c}42 \\
1 \\
2 \\
40 \\
1 \\
5 \\
36\end{array}$ & $\begin{array}{c}33.07 \% \\
0.78 \% \\
1.57 \% \\
31.49 \% \\
0.78 \% \\
3.93 \% \\
28.34 \%\end{array}$ \\
\hline $\mathrm{O}_{54}$ & $\begin{array}{l}\mathrm{N}-44.2332, \\
\mathrm{E}-24.3649, \\
\text { max.r.l. }-42 \mathrm{~m} \text {, min.r.l. - } 13 \mathrm{~m} \text {, } \\
\text { max.w.d. }-1.5 \mathrm{~m}\end{array}$ & $\begin{array}{c}S c \\
A a \\
A b \\
R k \\
C a g \\
S a\end{array}$ & $\begin{array}{c}17 \\
2 \\
1 \\
7 \\
325 \\
5\end{array}$ & $\begin{array}{c}4.76 \% \\
0.56 \% \\
0.28 \% \\
1.96 \% \\
91.03 \% \\
1.40 \%\end{array}$ \\
\hline $\mathrm{O}_{55}$ & $\begin{array}{l}\mathrm{N}-44.2296, \\
\text { E - 24.3978, } \\
\text { max.r.l. - } 47 \mathrm{~m}, \text { min.r.l. - } 24 \mathrm{~m} \text {, } \\
\text { max.w.d }-1 \mathrm{~m}\end{array}$ & $\begin{array}{c}S c \\
A a \\
R k \\
C a g \\
L g \\
A c\end{array}$ & $\begin{array}{c}4 \\
7 \\
25 \\
1 \\
1 \\
2\end{array}$ & $\begin{array}{c}10 \% \\
17.5 \% \\
62.5 \% \\
2.5 \% \\
2.5 \% \\
5 \%\end{array}$ \\
\hline $\mathrm{O}_{56}$ & $\begin{array}{l}\mathrm{N}-44.2231, \\
\mathrm{E}-24.4359, \\
\text { max.r.l. - } 95 \mathrm{~m}, \text { min.r.l. - } 80 \mathrm{~m} \text {, } \\
\text { max.w.d. - } 2.5\end{array}$ & $\begin{array}{c}S c \\
A a \\
R k \\
C c \\
C a g \\
L g \\
A c\end{array}$ & $\begin{array}{c}3 \\
17 \\
15 \\
1 \\
99 \\
3 \\
2\end{array}$ & $\begin{array}{c}2.14 \% \\
12.14 \% \\
10.71 \% \\
0.71 \% \\
70.71 \% \\
2.14 \% \\
1.42 \%\end{array}$ \\
\hline $\mathrm{O}_{56}$ & $\begin{array}{l}\mathrm{N}-44.2231, \\
\mathrm{E}-24.4359, \\
\text { max.r.l. - } 95 \mathrm{~m} \text {, min.r.l. - } 80 \mathrm{~m} \text {, } \\
\text { Maximum water depth - } 2.5 \mathrm{~m}\end{array}$ & $\begin{array}{c}E l \\
A b r \\
A a \\
R s a \\
P p a \\
P f \\
P c \\
S q\end{array}$ & $\begin{array}{l}+ \\
+ \\
+ \\
+ \\
+ \\
+ \\
+ \\
+\end{array}$ & $\begin{array}{l}+ \\
+ \\
+ \\
+ \\
+ \\
+ \\
+ \\
+\end{array}$ \\
\hline
\end{tabular}

The high river water volume (Fig. 24), the presence of only fine sand river bed sectors (Fig. 26), the lowland aquatic plants areas, the slow water speed and the relatively meandered course are the natural explanation for the local fish fauna shifting to the carp zone.

The deviations of the ichthyofauna structure from the natural ones (Bănărescu, 1964) in these sectors can be explained by the local human impacts like: pollution, habitat modifications (Figs. 28 and 29), improper wastes management (Fig. 25) and illegal fishing.

CF-IBI score vary between 30 and 22, reflecting a decrease abundance of sensitive species, some expected species absent or rare, omnivores and tolerant species dominant. 


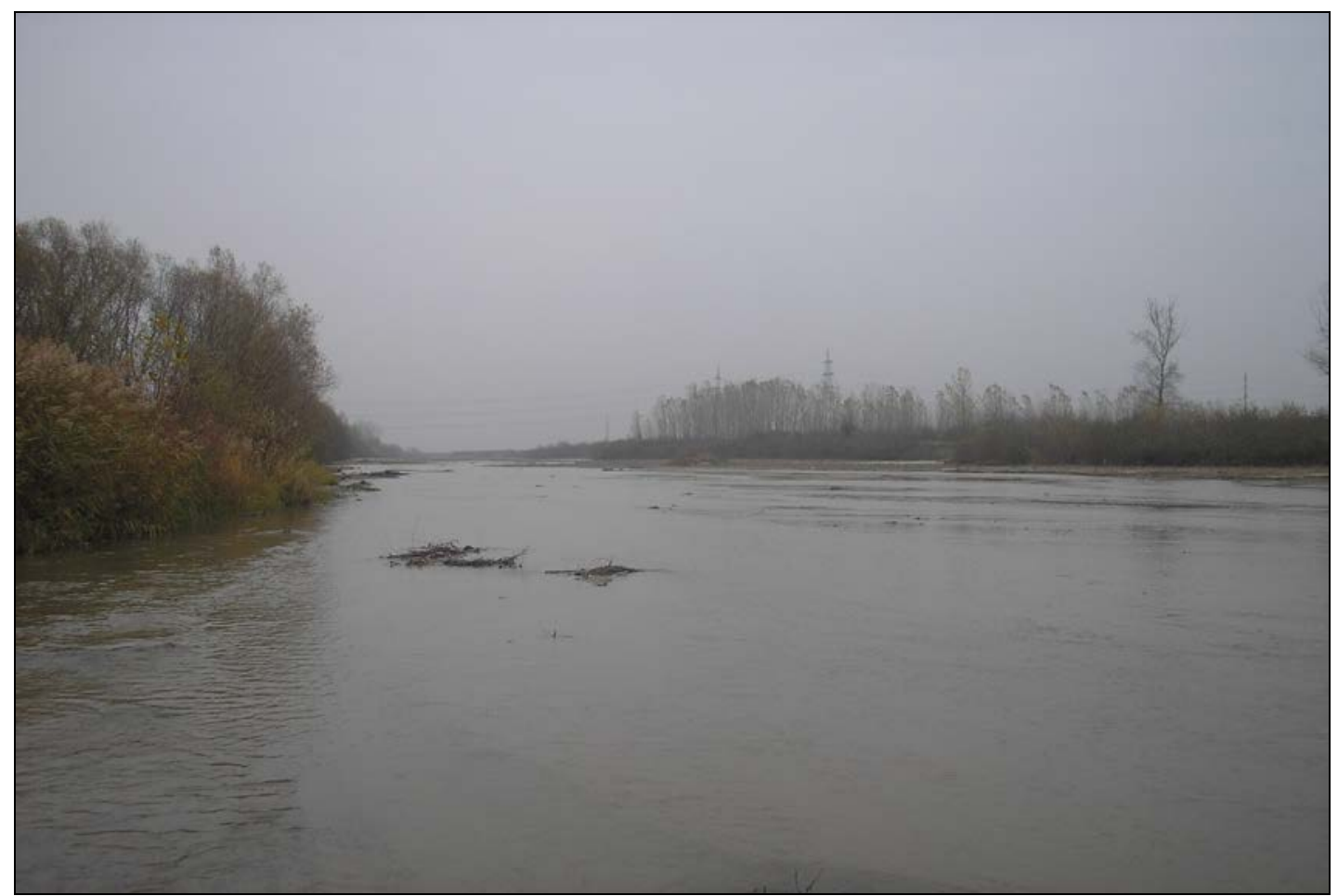

Figure 24: Characteristic habitat in the lower sector of Olteţ River.

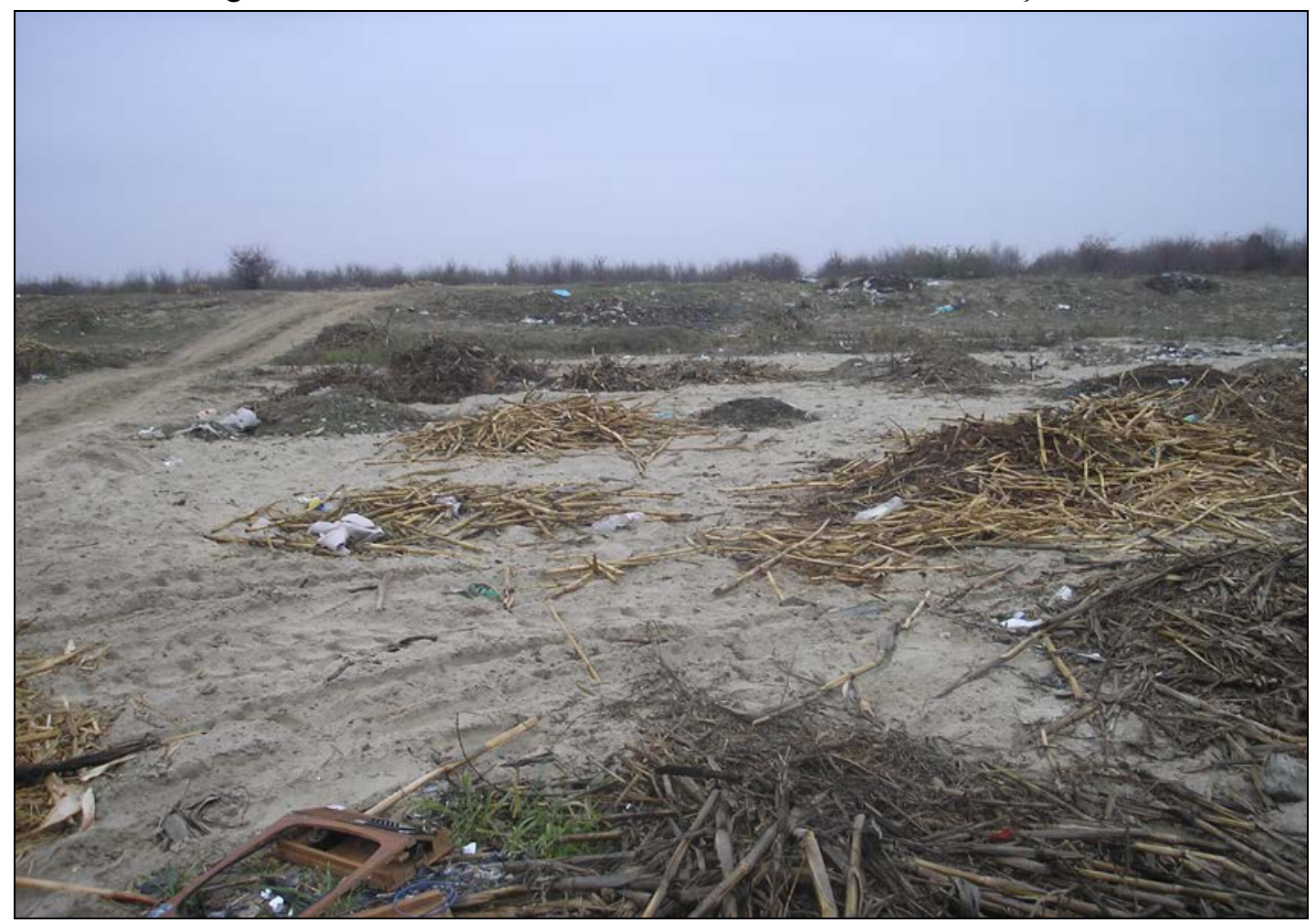

Figure 25: The constant presence of solid waste on the river banks. 


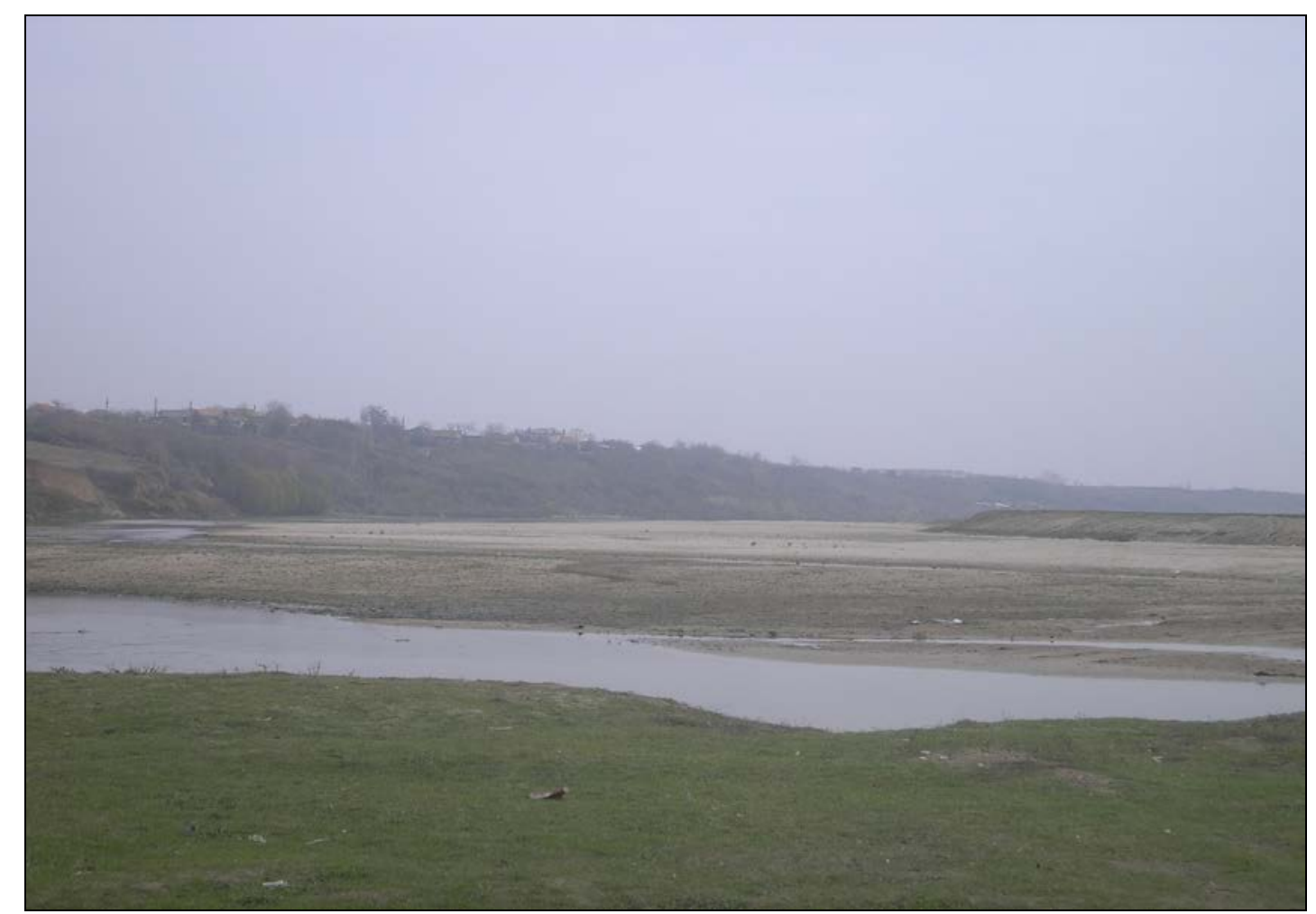

Figure 26: Lower course of Olteţ River.

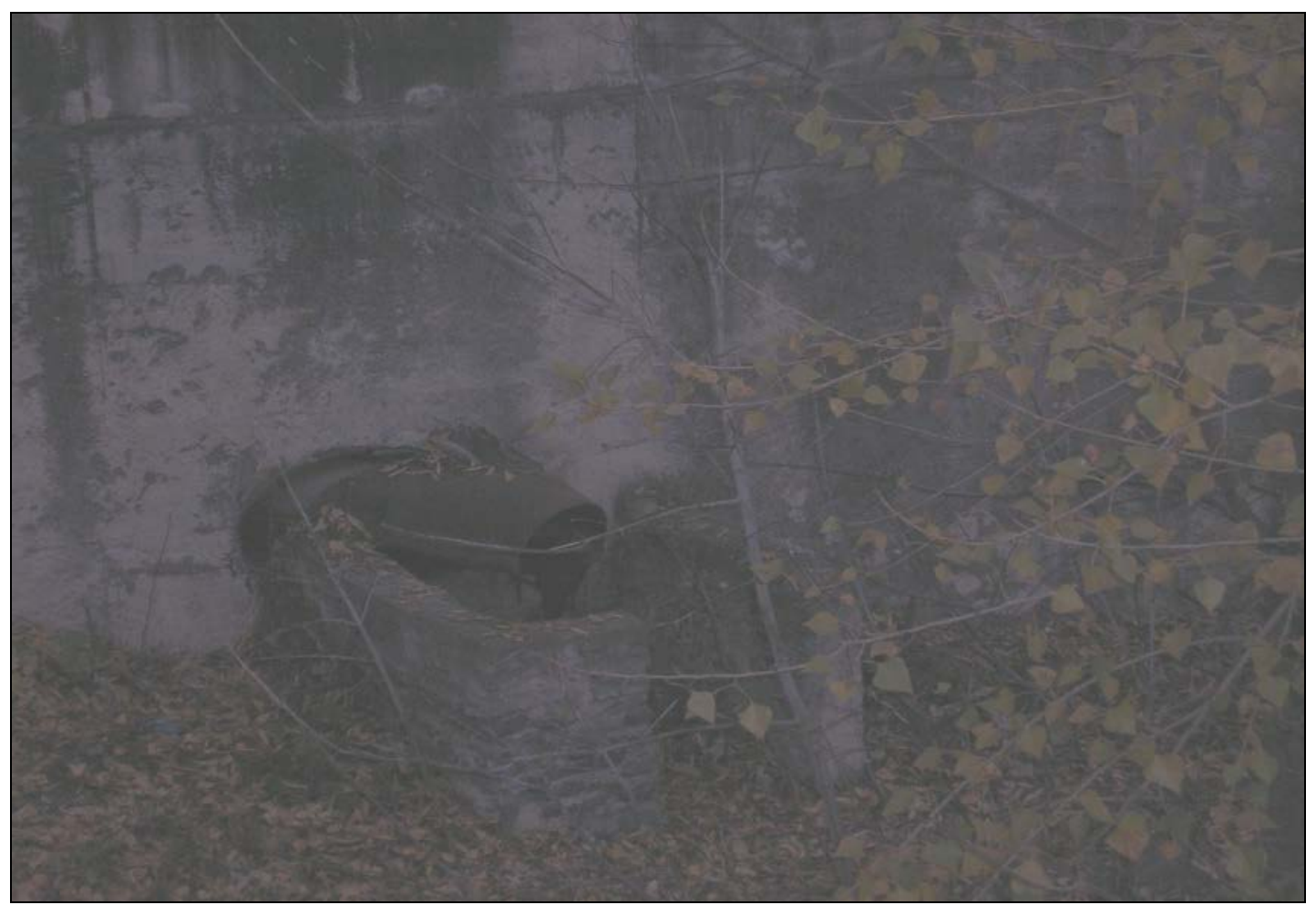

Figure 27: Direct polluted spills in the river in Balş urban area. 


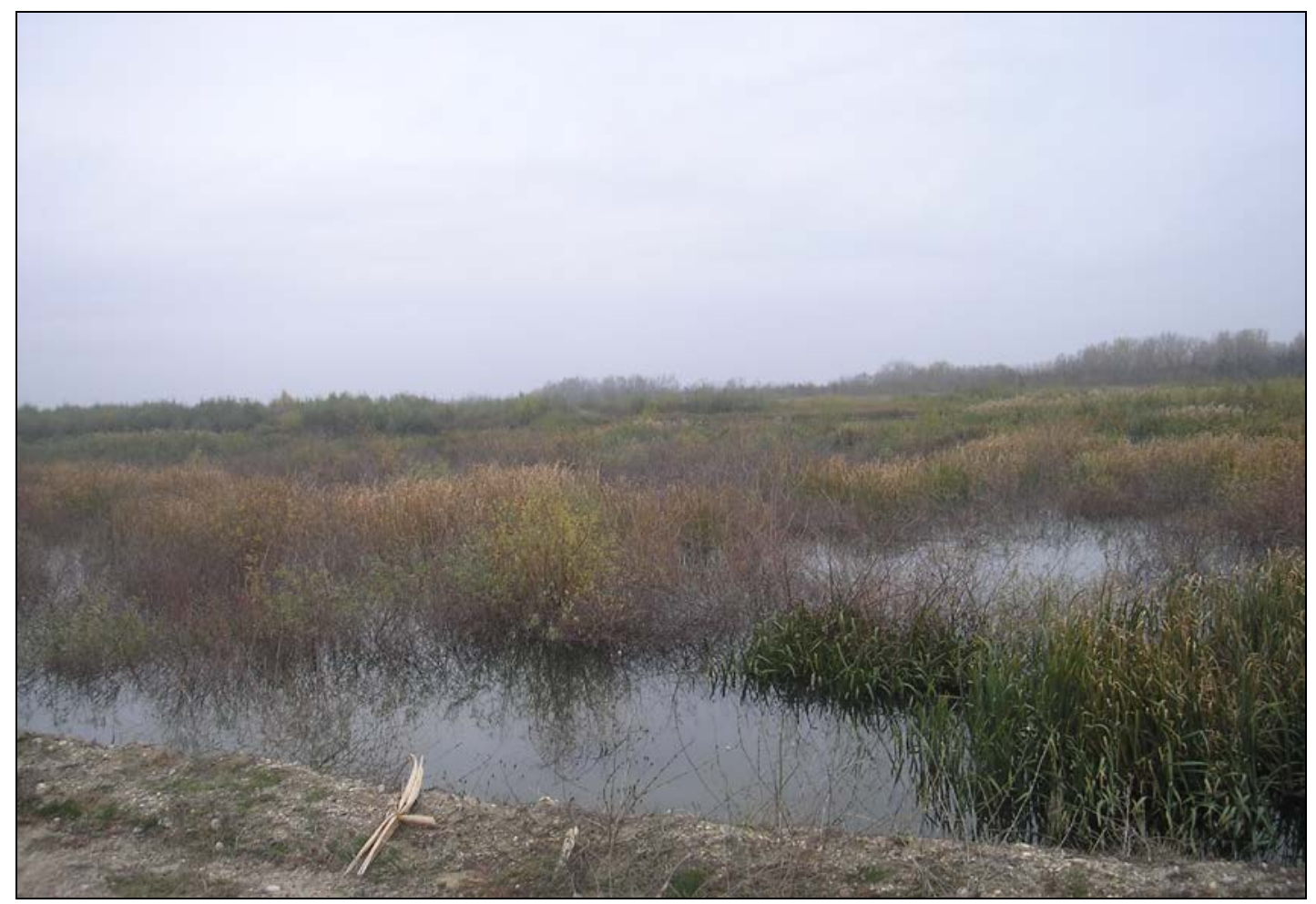

Figure 28: Olteţ River, four km from its confluence with Olt River.

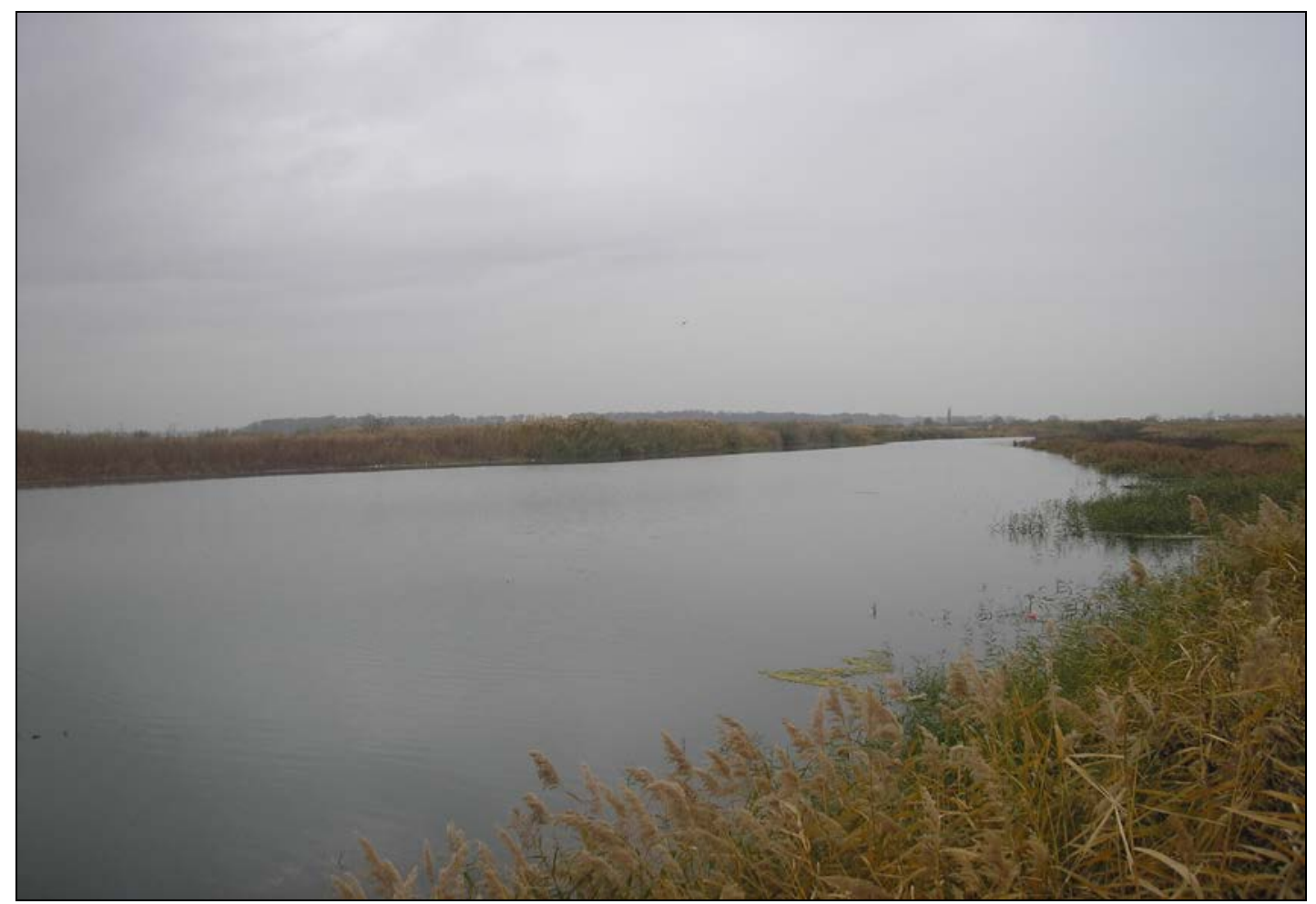

Figure 29: Natural flow of Olteţ River at one km from the confluence with Olt River. 


\section{DISCUSSION}

From the perspective of the local fish ichthyofauna associations, the $\mathrm{O}_{1-15}$ sector represents the upper trout zone in a relatively pristine area. $\mathrm{O}_{54-56}$ sections represent the most typical habitats for the plain macro habitats of Olteţ River, the exception of $\mathrm{O}_{55}$ sector is caused by the human impact in the locality Fălcoiu $\left(\mathrm{O}_{55}\right) \cdot \mathrm{O}_{16-17-21}$ has a close degree of similarity because the local fish ichthyocenoses react to the effects of the riverbed exploitations. $\mathrm{O}_{50-52-55}$ has a close degree of similarity because the local fish ichthyocenoses react to a certain communal (Barza, Şopârlița and Fălcoiu) human impact in a low land macro habitats type. $\mathrm{O}_{1-13}$ is in a typically mountainous/Carpathian area and $\mathrm{O}_{14-18}$ is in a typically submountainous/subcarpathian zone, its lower part, $\mathrm{O}_{16-18}$ sector, being strongly influenced by the human impact. $\mathrm{O}_{18-19}$ has a close degree of similarity because the local fish ichthyocenoses react to the presence of concrete medium sized (two m) dams.

Using the graph (Fig. 30) where the interrupted columns represent the stations where the number of species increases from the previous station, the black columns represent the number of species that decrease from the previous station and the grey columns represent those stations that have the same number of species with the previous station; we can emphasize the fact that there are many variations in species number, either because of the basic natural/geographic causes or due to anthropogenic causes.

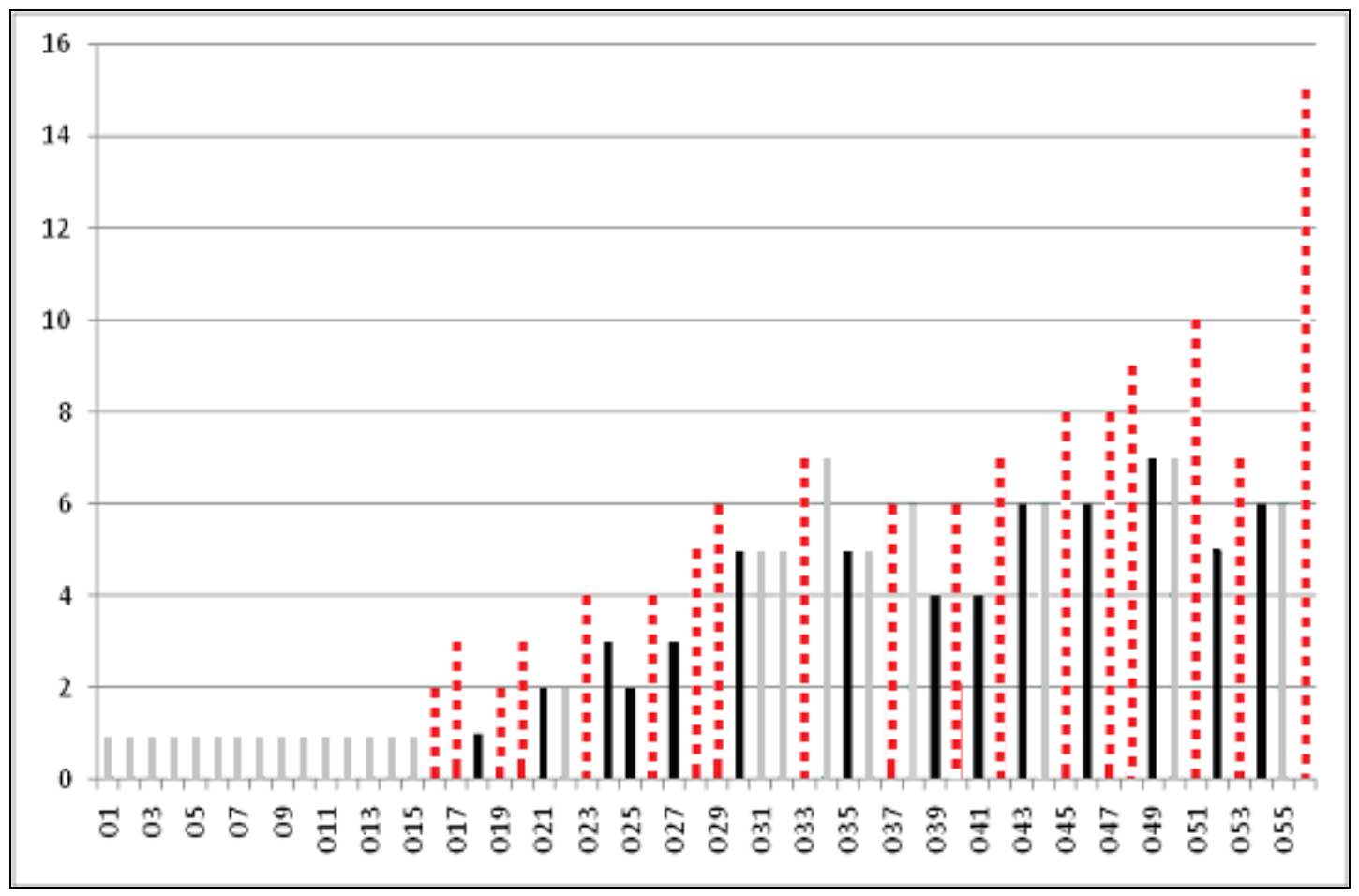

Figure 30: Fluctuations of fish species in each station on the course of Olteţ River.

The increasing of fish species number in 16-17, 19-20, 26, 29, 40, 47-48, 53, 56, sampling sectors reveal the natural changing of the ichthyological zone due to the river passing from one type of geographical/relief unit category to another category.

The unnatural decreasing of fish species number in the 18, 21, 24-25, 27, 30, 35, 39, $41,43,46,49,52,54$, sampling sectors have a human activities impact origin. 
Other cases of river sectors $(23,28,33,37,40,42,45,51)$ where the fish species number increase without a connection with the geographical/relief units changing, is represented through recovering of the river habitats quality due to natural self-cleaning processes downstream of some anthropogenicaly impacted river sectors. It can be noticed that the recovery period, based on distances on the downstream sectors with problems, are faster in the upper ichthyological zones and slower in the lower ichthyological zones. This meaning that the fish communities' characteristics for the lower course of the river are easier to be negatively affected by the human impact than the upper one, at least in the Oltet River case. The slower self-cleaning capacity of the river and the much easier natural access of the humans to the river (localities, activities, etc.) can be explanations.

The fish communities' similarity in the 56 sampled lotic sectors along the Oltet River, based on the relative abundance of the component fish species, reveal the relation among the ichthyologic zones (Bănărescu, 1964) and some specific habitats presence, related also with significant different geographical units (Fig. 31).

In general, the passing of the river from one type of geographical/relief type unit to another induces the changing of the ichthyological zone and the increase of the fish species number. The cases where this situation did not appear are because different human impacts create unnatural variations in fish communities' compositions and individuals' number. It highlighted the fact that the geographical elements, human impact and the self-cleaning capacity of the river are the main driving forces which induce the fish fauna variability.

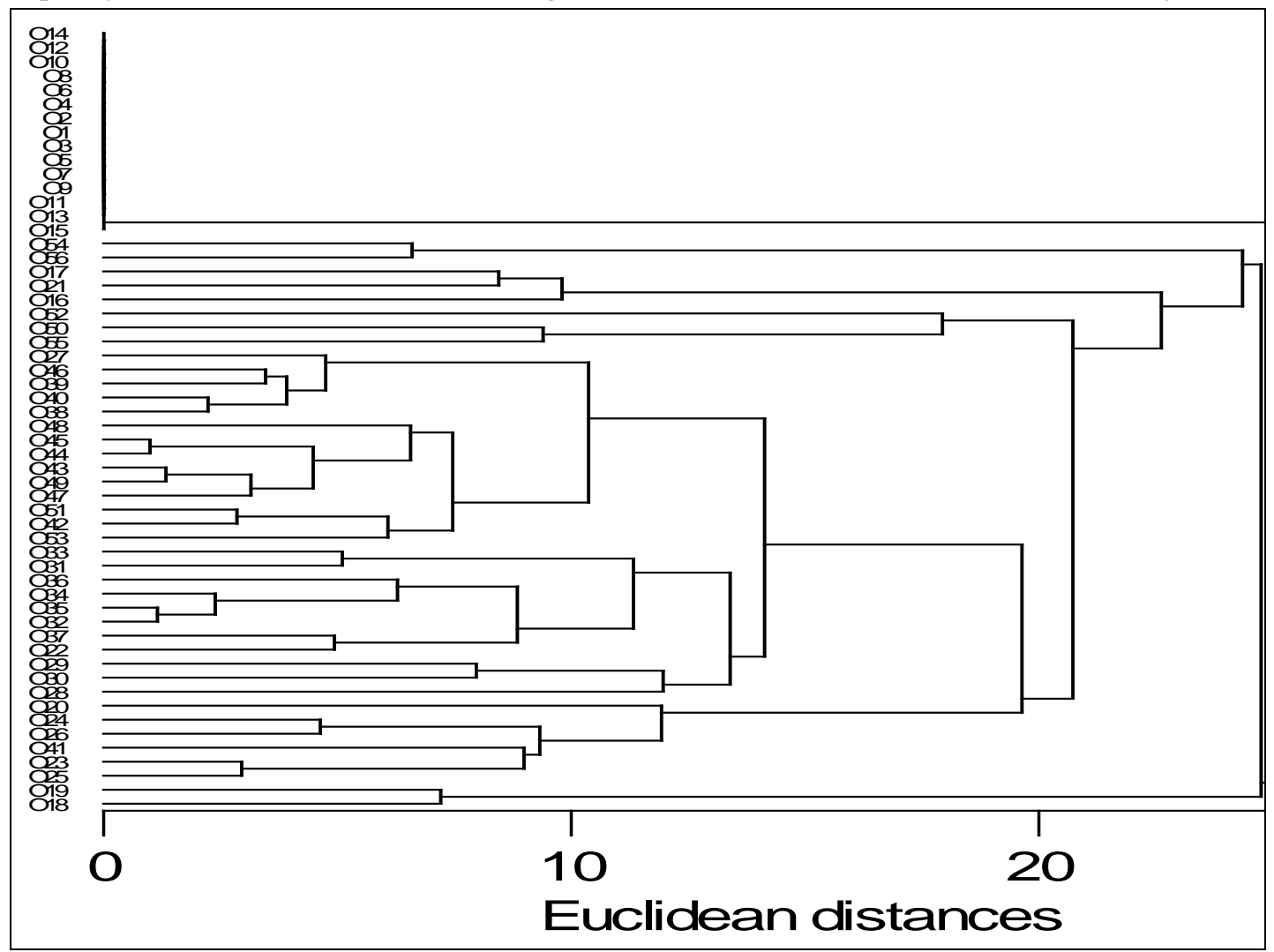

Figure 31: The fish communities’ similarity along Olteț River, based on the component species relative abundance. 
A half of the century which passes from the Bănărescu fish fauna study (1964) of the Oltet River lower sector, reveals significant modifications in ichthyofauna structure (Tab. 6) mainly due to significant habitat changes such as the creation of an important lenitic area at the Oltet-Olt confluence.

Table 6: Ichthyofauna (1960s/present) in the Balş city to the Olteţ-Olt rivers confluence sector.

\begin{tabular}{|l|l|l|}
\hline \multicolumn{1}{|c|}{1960 s } & \multicolumn{1}{|c|}{ Present } \\
\hline 1. & Gobio kessleri & Gobio kessleri \\
\hline 2. & Sabanejewia aurata balcanica & Sabanejewia aurata \\
\hline 3. & Sabanejewia romanica & Sabanejewia romanica \\
\hline 4. & Gobio gobio & Gobio gobio \\
\hline 5. & Leuciscus cephalus & Leuciscus cephalus \\
\hline 6. & Carassius auratus gibelio & Carrasius auratus gibelio \\
\hline 7. & Barbus barbus & Barbus barbus \\
\hline 8. & Alburnus alburnus & Alburnus alburnus \\
\hline 9. & Exos lucius & Exos lucius \\
\hline 10. & Cyprinus carpio & Cyprinus carpio \\
\hline 11. & Cobitis taenia & Cobitis taenia \\
\hline 12. & - & Barbus meridionalis \\
\hline 13. & - & Rodeus sericeus amarus \\
\hline 14. & - & Alburnoides bipunctatus \\
\hline 15. & - & Acerina cernua \\
\hline 16. & - & Lepomis gibosus \\
\hline 17. & - & Abramis brama \\
\hline 18. & - & Aspius aspius \\
\hline 19. & - & Perca fluviatilis \\
\hline 20. & - & Pelecus cultratus \\
\hline 21. & - & Silurus glanis \\
\hline & - & \\
\hline
\end{tabular}

Despite the fact that more than half of a century has passed from the moment when Mr. Bănărescu M. P. proposed a zonation of the fish fauna on the Romanian national territory specific natural conditions (a zonation which is generally valuable even today), there were no other applied studies which reveal more than a relation between the fish associations and the major relief units (mountain, hills, plain) respectively to some gradients induced by the altitudinal variation. On the other hand, the Carpathian Fish Index of Biotic Integrity (CF-IBI), and other such biotic indexes, can highlight the fish communities' ecological state variation, but cannot explain it. This study highlighted the possibility to explain the fish fauna variation in relation with smaller relief units presence and variation, smaller relief units characterized by distinct geological and geomorphologic (biotope) conditions (even sometimes overlapped in their neighbouring areas) of the lotic sectors. 
Naturally, there where the passing from one geographical/geological unit which appeared sharply, the ichthyological changes happened in relatively short sectors, and there where the biotopes characteristics changing gradually, gradually will appear the changes of ichthyofauna structure. In the last cases (e.g. Podişul Getic) it is more appropriate to work with ichthyological subzones, not only with ichthyological zones.

Even if the relation among geologic substrata $(G)$ - relief units (R) - preponderant aquatic macro habitat types (A) - ichthyologic structures (F), (GRAF) is relatively obvious for Oltet River, the necessity of this type of approach through identifying the trends and gradients among these elements than rigid and arbitrary limiting separations along the river should be understood.

The degree of relativeness of the relations among geologic substrata - relief units preponderant aquatic macro habitat types - ichthyologic structures (GRAF), increase in general under the increasing impact of many human impact categories, in these cases/sectors the interpretation of the fish fauna distribution and structure should be rather easy to interpretate.

The field effort (the relatively high number of sampling stations) necessary to such an approach is significantly higher than the majority of the fish inventory, assessment and monitoring types realized in the present Carpathians rivers.

In the less human influenced sectors, the ichthyologic classic zones (sensu Bănărescu 1964), have a better overlapping with the existent relief units which usually change together (mountain zones).

In the significant human influenced sectors, the ichthyologic classic zones (sensu Bănărescu 1964), have a relative overlapping with the existent relief units, the ichthyofauna changing are usually not immediate like in the mountainous zones (e.g. Polovraci Depression).

As far as the relief energy decrease, from high altitudes to low altitudes, the passing from one ichthyologic zone to the next one is far from the limit of one relief unit to the next one.

The natural passing from one ichthyologic zone to the next one can hardly be observed if the human impact is diversely present in those areas.

\section{CONCLUSIONS}

A white spot regarding the fish fauna of the upper and middle Oltet River was covered and the changes appeared in this respect and in the lower course were identified.

The passing of the river from one type of geographical/relief type unit to another induces the changing of the ichthyological zone and the increasing of the fish species number.

There where this natural situation did not appear is because different human impacts create unnatural variations in fish communities' compositions and individual numbers. The presence of various human impact, especially downstream the mountain area, make a relatively unbalanced fish fauna structure, in comparison with the mountainous sector.

Overall, the geographical and human impact elements, and a result of them, the selfcleaning capacity of the river, are the main driving forces which induce the fish fauna composition variability. 
If such studies will be repeated in other Carpathian rivers, a new index of relative overlapping ichthyofauna-relief units categories which highlights and explains the missing/presence/importance of the human impact on fish fauna structure can be proposed.

\section{ACKNOWLEDGMENTS}

The authors would like to thank the colleague Nistorescu M. and the students Mărginean M., Stroilă V. and Răchită R. for their support in the field, and for the interesting professional moments spent together along the Olteţ River. 


\section{REFERENCES}

1. Antipa G., 1909 - Fauna Ihtiologică a României, Bucureşti, Academia Română, Publicaţiile Fondului Adamachi, 294. (in Romanian)

2. Badea L. (coord.), 1983 - Geografia României I, Geografia Fizică, Edit. Academiei Române, 662. (in Romanian)

3. Bănărescu P., 1964 - Fauna Republicii Populare Romîne. Piscies-Osteichtyes (Peşti ganoizi şi osoşi), XIII, Edit. Academiei R. P. R., Bucureşti, 263-264. (in Romanian)

4. Bănăduc D., 1999 - Data concerning the human impact on the ichthyofauna of the upper and middle sectors of the Olt River, Transylvanian Review of Systematical and Ecological Research, Sîrbu et al., (eds), 1, Edit. Universităţii “Lucian Blaga” din Sibiu, ISSN 1841-7051, ISBN 973-9410-69-3, 157-164.

5. Bănăduc D., 2000 - Ichthyofaunistic criteria for Cibin River human impact assesment, Travaux du Museum National d Histoire naturelle Grigore Antipa, Bucureşti, XLII, 365-372.

6. Bănăduc D., 2001 - Ihtiofauna râului Lotrioara în Valea Lotrioarei, Edit. Mira Design, ISBN 973-632-243-2, 48-54.

7. Bănăduc D. and Curtean-Bănăduc A., 2002 - A biotic integrity index adaptation for a Carpathian (first-second order) river assesment, Acta oecologica, IX, 1-2, Edit. Universităţii “Lucian Blaga” din Sibiu, ISSN 1221-5015, 81-99.

8. Curtean-Bănăduc A. and Bănăduc D., 2004 - Cibin River fish communities structural and functional aspects, Studii şi Cercetări Ştiinţifice - Seria Biologie, Universitatea din Bacău, 9, ISSN 122-919-X, 93-102.

9. Curtean-Bănăduc A. and Bănăduc D., 2008 - Trophic elements regarding the non-indigenous Pseudorasbora parva (Schlegel) 1842 fish species spreading success - Olt River Basin, a case study, Romanian Journal of Bioloy-Zoology, 6, Edit. Academiei Române, 185-196.

10. Curtean-Bănăduc A., Schneider-Binder E. and Bănăduc D., 2014 - The importance of the riverine ligneous vegetation for the Danube Basin lotic ecosystems, in Cianfaglione K. (ed.), L’importanza degli Alberi e del Bosco. Cultura, scienza e coscienza del territorio, I-II, Temi Edit. Trento, Italia, ISBN 978-88-973772-63-9.

11. Diaconu C. and Stănculescu S., 1971 - Rîurile României, Monografie Hidrologică, Institutul de Meteorologie şi Hidrologie, 750.

12. Mutihac V., 1990 - Structura geologică a teritoriului României, Edit. Tehnică, Bucureşti, ISBN 973-31-0193-8, 418. (in Romanian)

13. Posea G. (coord.), 1982 - Enciclopedia Geografică a României, Edit. Ştiinţifică şi Enciclopedică, Bucureşti, 847. (in Romanian)

14. Posea G. (coord.), 1983 - Enciclopedia Geografică a României, Edit. Ştiinţifică şi Enciclopedică, Bucureşti, 847. (in Romanian)

15. Roşu A., 1973 - Geografia fizică a României, Edit. Didactică şi Pedagogică, Bucureşti, 435. (in Romanian)

16. Roşu A., 1980 - Geografia României, Edit. Didactică şi Pedagogică, Bucureşti, 482. (in Romanian)

17. Sommerwerk N., Baumgartner C., Bloesch J., Hein T., Ostojic A., Paunović M., SchneiderJacoby M., Siber R. and Tockner K., in Tockner K., Uehlinger U. and Robinson C. T., 2009 Rivers of Europe, chapter 3, The Danube River Basin, 59-112.

18. Tufescu V., 1966 - Subcarpaţii şi depresiunile marginale ale Transilvaniei, Edit. Ştiinţifică, Bucureşti, 254. (in Romanian)

19. Ujvári I., 1972 - Hidrografia Republicii Socialiste România, Bucureşti, Edit. Ştiinţifică, 590 (in Romanian) 
20. Velcea V. and Savu A., 1982 - Geografia Carpaţilor şi a Subcarpaţilor Româneşti, Edit. Didactică şi Pedagogică, Bucureşti. (in Romanian) 